SRNL-STI-2011-00613

Revision 0

\title{
STATISTICAL ANALYSIS OF TANK 5 FLOOR SAMPLE RESULTS (U)
}

\author{
E.P. Shine
}

March 2012

Computational Sciences

Savannah River National Laboratory

Aiken, SC 29808

This document was prepared in conjunction with work accomplished under Contract No. DE-AC09-08SR22470 with the U.S. Department of Energy.

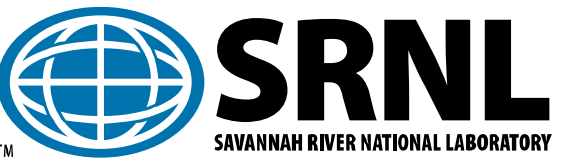


SRNL-STI-2011-00613

March 14, 2012

Revision 0

PAGE INTENTIONALLY LEFT BLANK 
Keywords:

Tank Sampling

Tank 5-F

Tank closure

Retention: permanent

\title{
STATISTICAL ANALYSIS OF TANK 5 FLOOR SAMPLE RESULTS (U)
}

\author{
E.P. Shine
}

March 14, 2012

Applied Computational Engineering and Statistics Savannah River National Laboratory Aiken, SC 29808

This document was prepared in conjunction with work accomplished under Contract No. DE-AC09-08SR22470 with the U.S. Department of Energy. 


\section{DISCLAIMER}

This work was prepared under an agreement with and funded by the U.S. Government. Neither the U.S. Government or its employees, nor any of its contractors, subcontractors or their employees, makes any express or implied: 1 . warranty or assumes any legal liability for the accuracy, completeness, or for the use or results of such use of any information, product, or process disclosed; or 2. representation that such use or results of such use would not infringe privately owned rights; or 3. endorsement or recommendation of any specifically identified commercial product, process, or service. Any views and opinions of authors expressed in this work do not necessarily state or reflect those of the United States Government, or its contractors, or subcontractors.

This document was prepared in conjunction with work accomplished under Contract No. DE-AC09-08SR22470 with the U.S. Department of Energy. 


\section{REVIEWS AND APPROVALS}

\section{AUTHOR:}

E. P. Shine, Applied Computational Engineering and Statistics

Date

Savannah River National Laboratory

\section{TECHNICAL REVIEWER:}

T. B. Edwards, Applied Computational Engineering and Statistics Date Savannah River National Laboratory

\section{APPROVERS:}

P. E. Carroll, Closure Engineering

Date

Savannah River Remediation LLC

W. B. Dean, Closure and Waste Disposal Authority

Date

Savannah River Remediation LLC

P.L. Lee, Manager, Applied Computational Engineering and Statistics Date Savannah River National Laboratory

S. J. Hensel, Manager, Computational Engineering and Sciences

Date

Savannah River National Laboratory

F. M. Pennebaker, Manager, Advanced Characterization \& Processing Date Savannah River National Laboratory 


\section{List of Tables}

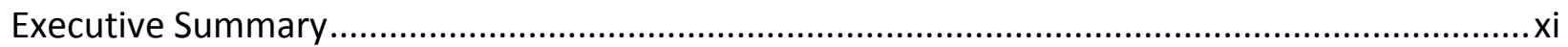

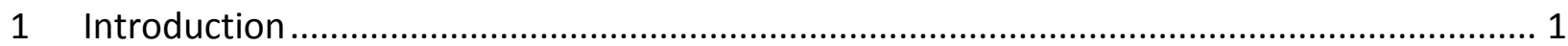

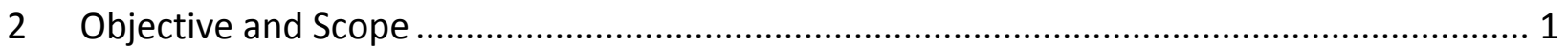

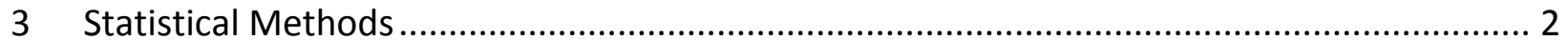

3.1 All Measurements above their Minimum Detectable Concentrations................................ 3

3.2 All Measurements below their Minimum Detectable Concentrations .............................. 6

3.3 Measurements that are a Mixture of Results above and below their............................... 6

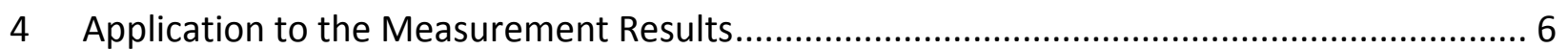

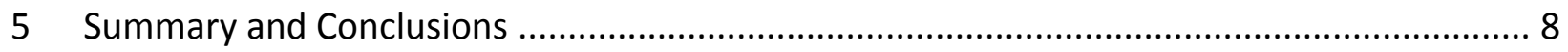

Appendix A. Measurement Results from the SRNL Analytical Laboratory............................... 10

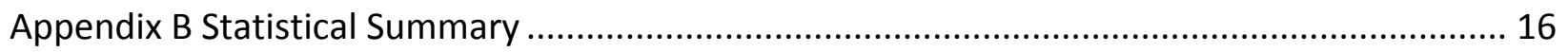

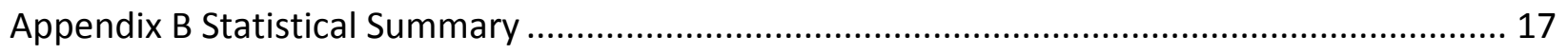




\section{List of Figures}

Figure 1. Sequence of Goodness-of-Fit Tests to Identify a Distribution and Select an Estimation Method

\section{List of Tables in Appendix A}

Table A1. Composite Sample Bulk Density (g/mL). 10

Table A2. Radionuclides with All Measurements ( $\mu \mathrm{Ci} / \mathrm{g}$ ) above their Minimum Detectable Concentrations.

Table A2 Continued. Radionuclides with All Measurements $(\mu \mathrm{Ci} / \mathrm{g})$ above their Minimum Detectable Concentrations

Table A3. Radionuclides with All Measurements ( $\mu \mathrm{Ci} / \mathrm{g}$ ) below their Minimum Detectable Concentrations

Table A4. Radionuclides with a Mixture of Measurements $(\mu \mathrm{Ci} / \mathrm{g})$ above and below their Minimum Detectable Concentrations

Table A5. Inorganics with All Measurements (mg/g) above their Minimum Detectable Concentrations

Table A6. Inorganics with All Measurements (mg/g) below their Minimum Detectable Concentrations

Table A7. Inorganics with a Mixture of Measurements $(\mathrm{mg} / \mathrm{g})$ above and below their Minimum Detectable Concentrations....

Table A8. Anions with All Measurements $(\mathrm{mg} / \mathrm{g}$ ) above their Minimum Detectable Concentrations

Table A9. Anions with All Measurements $(\mathrm{mg} / \mathrm{g})$ below their Minimum Detectable Concentrations.

Table A10. Anions with a Mixture of Measurements $(\mathrm{mg} / \mathrm{g})$ above and below their Minimum Detectable Concentrations . 


\section{List of Tables in Appendix B}

Table B1. Statistical Summary for the Sample Bulk Density $(\mathrm{g} / \mathrm{mL})$ 16

Table B2. Statistical Summary for the Radionuclides $(\mu \mathrm{Ci} / \mathrm{g})$ - All Measurements above their Minimum Detectable Concentrations .....

Table B3. Statistical Summary for the Radionuclides $(\mu \mathrm{Ci} / \mathrm{g})$ - All Measurements below their Minimum Detectable Concentrations

Table B4. Statistical Summary for the Radionuclides $(\mu \mathrm{Ci} / \mathrm{g})$ - Mixture of Measurements above and below their Minimum Detectable Concentrations....

Table B5. Statistical Summary for the Inorganics (mg/g) - All Measurements above their Minimum Detectable Concentrations

Table B5 Continued. Statistical Summary for the Inorganics (mg/g) - All Measurements above their Minimum Detectable Concentrations.

Table B6. Statistical Summary for the Inorganics (mg/g) - All Measurements below their Minimum Detectable Concentrations

Table B7. Statistical Summary for the Inorganics (mg/g) - Mixture of Measurements above and below the Minimum Detectable Concentrations

Table B8. Statistical Summary for the Anions (mg/g) - All Measurements above their Minimum Detectable Concentrations

Table B9. Statistical Summary for the Anions (mg/g) - All Measurements below their Minimum Detectable Concentrations

Table B10. Statistical Summary for the Anions (mg/g) - Mixture of Measurements above and below their Minimum Detectable Concentrations. 


\section{Executive Summary}

Sampling has been completed for the characterization of the residual material on the floor of Tank 5 in the F-Area Tank Farm at the Savannah River Site (SRS), near Aiken, SC. The sampling was performed by Savannah River Remediation (SRR) LLC using a stratified random sampling plan with volume-proportional compositing. The plan consisted of partitioning the residual material on the floor of Tank 5 into three non-overlapping strata: two strata enclosed accumulations, and a third stratum consisted of a thin layer of material outside the regions of the two accumulations. Each of three composite samples was constructed from five primary sample locations of residual material on the floor of Tank 5. Three of the primary samples were obtained from the stratum containing the thin layer of material, and one primary sample was obtained from each of the two strata containing an accumulation.

This report documents the statistical analyses of the analytical results for the composite samples. The objective of the analysis is to determine the mean concentrations and upper $95 \%$ confidence (UCL95) bounds for the mean concentrations for a set of analytes in the tank residuals. The statistical procedures employed in the analyses were consistent with the Environmental Protection Agency (EPA) technical guidance by Singh and others [2010].

Savannah River National Laboratory (SRNL) measured the sample bulk density, nonvolatile beta, gross alpha, radionuclide ${ }^{1}$, inorganic, and anion concentrations three times for each of the composite samples. The analyte concentration data were partitioned into three separate groups for further analysis: analytes with every measurement above their minimum detectable concentrations (MDCs), analytes with no measurements above their MDCs, and analytes with a mixture of some measurement results above and below their MDCs. The means, standard deviations, and UCL95s were computed for the analytes in the two groups that had at least some measurements above their MDCs. The identification of distributions and the selection of UCL95 procedures generally followed the protocol in Singh, Armbya, and Singh [2010]. When all of an analyte's measurements lie below their MDCs, only a summary of the MDCs can be provided. The measurement results reported by SRNL are listed in Appendix A, and the results of this analysis are reported in Appendix B. The data were generally found to follow a normal distribution, and to be homogenous across composite samples.

\footnotetext{
${ }^{1}$ A subset of the radionuclides, Al-26, Cl-36, K-40, Nb-94, Sn-126, Sb-126 and Sb-126m, Pd-107, Eu-152, Pt-193, Ra226, and Ac-227, was not easily measurable by standard methods due to their presence at low concentrations in the samples. Only one analysis per sample was required due to the confirmatory nature of their measurements.
} 


\section{Introduction}

Sampling has been completed for the characterization of the residual material on the floor of Tank 5 in the F-Area Tank Farm at the Savannah River Site (SRS), near Aiken, SC. The sampling was performed by Savannah River Remediation LLC (SRR) using a stratified random sampling plan with volume-proportional compositing, Dean [2011]. The plan consisted of partitioning the residual material on the floor of Tank 5 into three non-overlapping strata: two strata enclosed accumulations, and a third stratum consisted of a thin layer of material outside the regions of the two accumulations.

Each of three composite samples was constructed from five primary samples of material obtained directly from the residual material on the floor of Tank 5. A total of 15 primary samples were obtained in all. Three of the primary samples were obtained from the stratum containing the thin layer of material, and one primary sample was obtained from each of the two strata containing an accumulation for each composite sample. The volume of residual material in each of the three strata was estimated along with an uncertainty of the volume estimate. A separate set of strata volumes was randomly generated for each composite sample from the volume uncertainty distributions, Dean [2011]. All three strata volumes were converted into volumetric proportions, and subsequently to the mass of residual material to be used from each primary sample for its corresponding composite sample. This procedure directly incorporates the volume uncertainty into the variation among the analyte concentrations in the composite samples, Shine [2011]. Each composite sample was measured three times ${ }^{2}$ for all but a few radionuclide concentrations.

A remote-controlled crawler was designed to collect the sample material. Tank 5 contains an extensive network of cooling coils that fettered movement of the crawler across the tank floor. Consequently, sample locations within strata were selected based on their accessibility to the crawler. However, it is assumed that earlier stages of cleaning/mixing of the material in the tank raised particles off the tank floor, and then deposited them in random locations, so the sample collection was effectively based on random sampling.

\section{Objective and Scope}

The objective of this report is to perform a statistical analysis of the chemical and isotopic concentration results for the residual material on the floor of Tank 5 . The approach is to use samples representative of the material from the tank floor to estimate the concentrations of analytes in the remaining residual material. The concentration results are summarized by the means and standard deviations of the composite sample concentrations. Upper $95 \%$ confidence

\footnotetext{
${ }^{2}$ A subset of the radionuclides, Al-26, Cl-36, K-40, Nb-94, Sn-126, Sb-126 and Sb-126m, Pd-107, Eu-152, Pt-193, Ra226, and Ac-227, was not easily measurable by standard methods due to their presence at low concentrations in the samples. Only one analysis per sample was required due to the confirmatory nature of their measurements.
} 
limits (UCL95s) are calculated for the mean concentration of each analyte that had measurement results above its minimum detectable concentration (MDC).

\section{Statistical Methods}

Each of three composite samples was formed from material from a separate set of five different primary samples. The material in each composite sample is considered to be representative of all of the residual material on the floor of Tank 5, and thus the measured concentration for any analyte in a composite sample is considered to be an independent estimate of the actual mean concentration of the analyte in the residual material on the entire tank floor. Three concentration measurements were performed for each analyte on each composite sample. The statistical measurement error model for a concentration measurement result $Y_{i j}$ is

$$
Y_{i j}=\mu+s_{i}+\varepsilon_{i j},
$$

where $Y_{i j}$ is the $j$-th measured concentration for an analyte in composite sample $i, \mu$ is the actual mean concentration for all of the residual material on the floor of Tank $5, s_{i}$, the sampling error, is a random effect that expresses the difference between the actual mean concentration in composite sample $i$ and the actual mean concentration for all of the residual material on the tank floor that arises from heterogeneity, sampling, sample preparation, and volumetric proportion errors, and $\varepsilon_{i j}$, distributed with mean zero and standard deviation $\sigma$, is the difference between concentration measurement $j$ on sample $i$ and the actual mean concentration in composite sample $i, i=1,2,3 ; j=1,2,3$.

A test for heterogeneity of measurement variance was performed prior to other analyses in order to verify the assumption that the composite sample material is well-mixed and the measurement variance $\sigma^{2}$ is the same for all composite samples. The test procedure is the Levene's test with a Type I family-wise error rate $\alpha=0.05$. Since the sample sizes are small (no more than three measurement results per composite sample), a Bonferroni procedure is used to control for spuriously significant results by dividing the 0.05 family-wise error rate by the number of comparisons to obtain the Type I error rate per comparison.

An analysis of variance (ANOVA) $F$ test was performed in order to determine whether the random effect $s_{i}$ is warranted in Eqn (1). If the $F$ test results indicate a statistically significant sampling error $s_{i}$ at level of significance $\alpha=0.05$, then Eqn (1) becomes the basis for estimating the true mean concentration in the residual material; if the ANOVA $F$ test result is not statistically significant, then the random effect $s_{i}$ is not needed and Eqn (1) reduces to the following:

$$
Y_{i j}=\mu+\varepsilon_{i j}
$$

where there is no sampling error term $s_{i}$ in the model. 


\subsection{All Measurements above their Minimum Detectable Concentrations}

If all of the concentration measurements for an analyte are above detection, then the ANOVA $F$ test can be performed, and a decision made to use the model in Eqn (1) with the random effect if $F \geq F_{0.95,2,6}=5.14325$, and to use the model in Eqn (2) without the random effect if $F<F_{0.95,2,6}=5.14325$. When $F \geq F_{0.95,2,6}=5.14325$, the UCL95 for the actual mean tank concentration is given by

$$
U C L_{95 \%}=\bar{Y}+t_{0.95,6 d f} \cdot \sqrt{\frac{M S_{\text {Random Effect }}}{9}}
$$

where $\overline{Y_{.}}$is the sample mean concentration of the nine concentration measurement results, and $M S_{\text {Randomeffect }}$ is the estimate of the mean square for the random effect $s_{i}$ in the model in Eqn (1), where

$$
M S_{\text {Random Effect }}=\frac{\sum_{i=1}^{3} \frac{Y_{i \cdot}^{2}}{3}-\frac{Y_{.}^{2}}{9}}{6},
$$

and $Y_{i}$. and $Y$. are the total of the three measured concentration results for composite sample $i, \quad i=1,2,3$ and the total of the nine measured concentration results for all three composite samples, respectively.

When $F<F_{0.95,2,4}=5.14325$, the UCL95 for the actual mean tank concentration is given by

$$
U C L_{95 \%}=\bar{Y}+t_{0.95,9-1 d f} \cdot \sqrt{\frac{s^{2}}{9}}
$$

where $s$ is the sample standard deviation of all nine measured concentration results.

The above procedures are appropriate if the data or a transform of the data approximately follow the normal distribution. Figure 1 presents a sequence of goodness-of-fit tests to identify a distribution consistent with the measurement results and select an estimation method for the mean, standard deviation, and UCL95. Studies by Singh, Singh, and Englehardt [1997] demonstrated that using the coefficient of variation (the percent standard deviation) is much less effective than using a formal goodness-of-fit test to determine whether the concentration measurements are consistent with a particular distribution such as the normal distribution. Consequently, the normal distribution assumption is tested by the Wilk-Shapiro (W-S) goodness-of-fit test at an $\alpha=5 \%$ level of significance. If the W-S statistic is less than the W-S critical value, then normality is rejected; if there is no statistically significant departure from 
normality, the mean, standard deviation, and UCL95 are estimated based on a normal distribution.

If the normal distribution assumption is rejected by the W-S test, then the measurements are tested to determine whether they are consistent with a skewed distribution. This report adopts the strategy in Singh, Armbya, and Singh [2010] to test for the gamma distribution prior to the lognormal distribution. The gamma distribution assumption is tested using Anderson-Darling (A-D) goodness-of-fit statistic. If the A-D statistic exceeds the A-D critical value then the gamma distribution assumption is rejected; if there is no statistically significant departure from the gamma distribution, the mean, standard deviation, and UCL95 are determined based on a gamma distribution. The UCL95 is based on the "approximate gamma UCL" documented by Singh, Singh, and Englehardt [1997]. If the gamma distribution is rejected, but a plot of the concentration results versus the theoretical gamma quantiles displays a linear pattern with high correlation (over 95\%), then the results are said to follow an approximate gamma distribution. The mean, standard deviation, and UCL95 are estimated assuming a gamma distribution, according to Singh, Armbya, and Singh [2010]. 


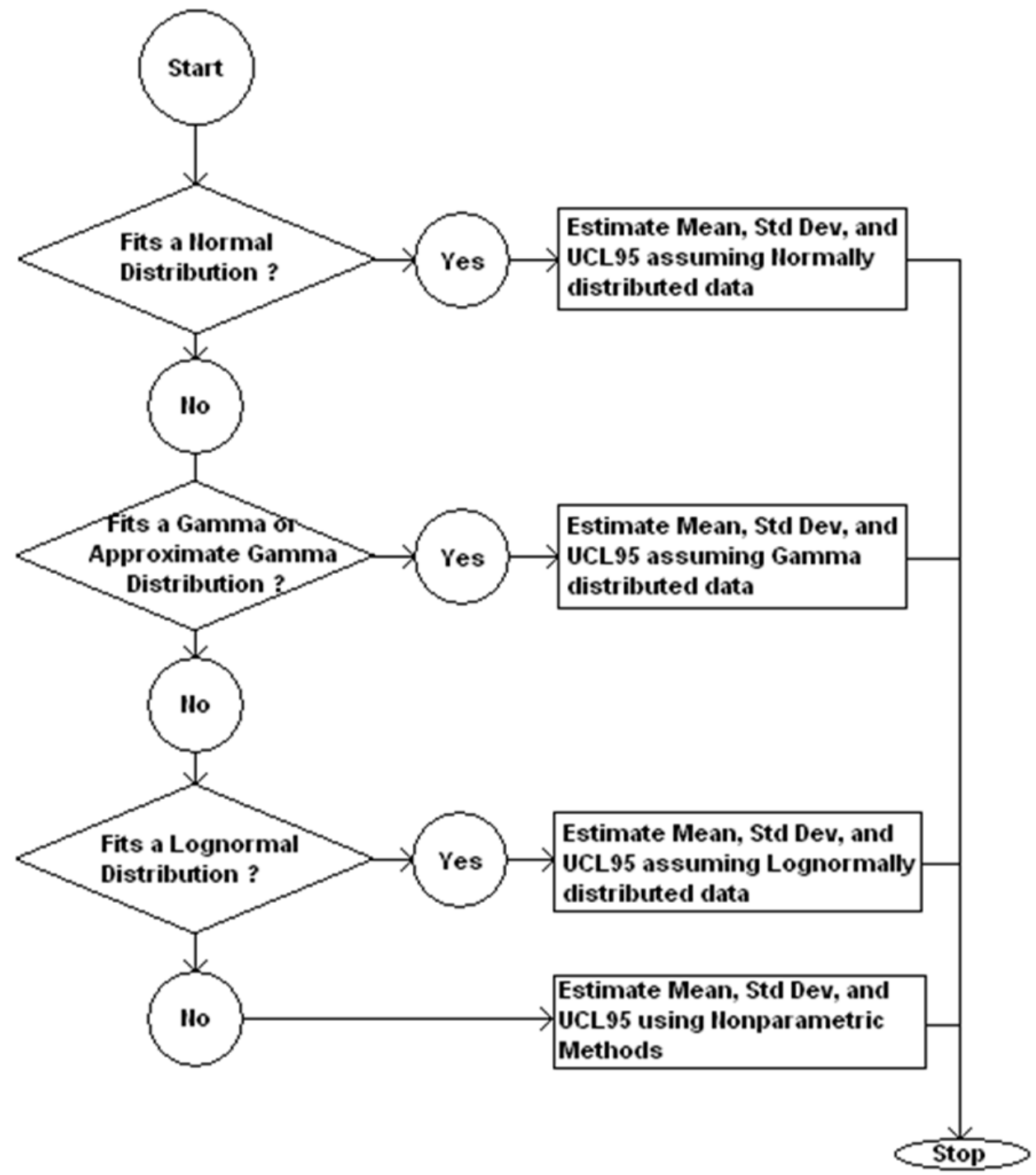

Figure 1. Sequence of Goodness-of-Fit Tests to Identify a Distribution and Select an Estimation Method

Finally, if the gamma distribution is rejected and the gamma quantile plot does not exhibit high correlation (>95\%), then the W-S goodness-of-fit test is used to determine if the measurements are consistent with the lognormal distribution. If the W-S statistic is less than the W-S critical value, then the lognormal assumption is vacated and a nonparametric approach to estimation is adopted; if the W-S test determines that the lognormal distribution is plausible, then the lognormal distribution is adopted. An appropriate UCL95 based on the lognormal distribution and the nonparametric Chebyshev UCL95 for use when the lognormal distribution is rejected are documented by Singh, Singh, and Englehardt [1997].

Homogeneity and ANOVA tests were performed in SAS JMP ${ }^{\circledR}$ [2010] software, and distribution plotting, goodness-of-fit tests, and parameter estimation were performed in ProUCL 4.1 [2010] software developed by Singh, Armbya, and Singh [2010]. 


\subsection{All Measurements below their Minimum Detectable Concentrations}

When all measurements for an analyte are below the MDC, the smallest and largest of the MDCs are reported.

\subsection{Measurements that are a Mixture of Results above and below their Minimum Detectable Concentrations}

The statistical estimation methods for sets of measurements with less-than-detection results are more complex than those for sets of measurements without less-than-detection results. However, the same sequence of tests is performed when there are less-than-detection results: normal, gamma, approximate gamma, then lognormal. The normal distribution assumption is tested at an $\alpha=5 \%$ level of significance. When some of the concentration measurements are above their MDCs and some of the concentration measurements are below their MDCs, maximum likelihood estimates of the mean and standard deviation can be obtained iteratively assuming that the measurements follow a normal distribution. The mean, standard deviation, and the Kaplan-Meier (KM) t UCL95 are calculated ${ }^{3}$ if the measured concentrations (including less-than-detect results) are consistent with the normal distribution. The UCL95 uses nonparametric KM estimates of the mean and standard deviation in Eqn (5). Formulae and computational software for the KM mean and standard deviation are given by Singh, Armbya, and Singh [2010].

If the normal distribution is rejected by the W-S goodness-of-fit test, then the gamma distribution is tested. The conservative KM Chebyshev UCL95 is calculated. Singh, Armbya, and Singh [2010] give the KM Chebyshev UCL95 by

$$
U C L 95=\widehat{\mu}_{x}+\sqrt{(1 / \alpha)-1} \tilde{\sigma}_{x} / \sqrt{n}=\widehat{\mu}_{x}+4.359 \tilde{\sigma}_{x} / \sqrt{n}
$$

where the KM estimates of $\mu$ and $\sigma$ are used in Eqn (6).

\section{$4 \quad$ Application to the Measurement Results}

Appendix A contains the composite measurement results reported by SRNL. Table A1 contains the results for the sample bulk density. Tables $A 2, A 3$, and $A 4$ contain results for the radionuclides: Table $A 2$ lists results for the nonvolatile beta and radionuclides with all of their measurements above their MDCs, Table A3 lists gross alpha and the radionuclides with all results below their MDC, and Table A4 lists the radionuclides that have some measurements above and some measurements below their MDCs.

\footnotetext{
${ }^{3}$ The Kaplan-Meier t UCL95 is the UCL95 for Student's t given in Eqn (5) using Kaplan-Meier estimates of the mean and standard deviation.
} 
Appendix A Tables A5, A6, and A7 present the measurement results for the inorganics: Table A5 lists the inorganics that have all of their measurement results above detection, Table A6 contains the inorganics that have all of their results below their MDCs, and Table A7 lists the one inorganic with some measurements above and some measurements below the MDCs.

Appendix A Tables A8, A9, and A10 present the measurement results for the anions: Table A8 lists the anions that have all of their measurement results above detection, Table A9 contains the anions that have all of their results below their MDCs, and Table A10 lists the anions with measurements above and below their MDCs.

All tests of variance homogeneity for the class of analytes with all measurements above detection failed to reject the hypothesis of homogeneity using a family-wise Bonferroni error rate of $\alpha$ /number of analytes $=0.05 / 66=0.00076$. Therefore, an ANOVA was used to test whether the composite sampling variance was greater than zero in Eqn (1). All results showed the composite sample variance to be zero, so Eqn (2) without a composite sample variance was adopted.

Appendix B Table B1 summarizes the statistical results for the sample bulk density. The descriptive statistical summary includes the number of measurements, the mean concentration, and the standard deviation of the concentrations. The percent standard deviation (100\% standard deviation / mean) was given next. The UCL95 for the mean density concentration is also provided in the table. The goodness-of-fit strategy described in Section 3.1 was used to determine the mean, standard deviation, and UCL95 for the density. A summary of the goodness-of-fit results is given in the right column of Appendix B Table B1.

The results for radionuclides, inorganics, and anions with all of their measurements above their MDCs are given in Appendix B Tables B2, B5, and B8, respectively. All of these tables are interpreted in the same manner as sample bulk density in Table B1.

Appendix B Tables B3, B6, and B9 contain the results for radionuclides, inorganics, and anions, respectively, which had all of their results below their MDCs. No means, standard deviations, or UCL95s can be provided in these cases. The smallest and the largest of the MDCs are reported.

Appendix B Tables B4, B7, and B10 contain the descriptive statistical summaries for radionuclides, inorganics, and anions, respectively, which have some of their results below detection and some of their results above detection. Calculations for the estimates of the means and the standard deviations are much more complex than the case where all measurements are above detection. The goodness-of-fit strategy outlined in Section 3.3 is summarized for each of these analytes in the right column of these tables. The maximum likelihood estimates for the true mean and true standard deviation of one analyte, U-234, failed to converge properly. The one U-234 measurement result below its MDC was replaced by $1 / 2$ of the MDC in the data prior to analysis, and the true mean and true standard deviation were estimated by sample mean and sample standard deviation, respectively. 


\section{Summary and Conclusions}

This report documents the statistical summary of the Tank 5 floor composite sample results. When all concentration results for an analyte were below their respective MDCs, then the smallest and the largest MDCs were reported.

When at least some of the concentration results were above their respective MDCs, the concentration results were treated as though they came from the same distribution because the ANOVA results indicated a lack of a sampling error (homogeneity) in the composite samples. Then the estimates of the mean, the standard deviation, the percent standard deviation, and the UCL95 were obtained from a distribution determined by goodness-of-fit testing. The order of testing distribution goodness-of-fit was adopted from a recent EPA technical report and computational software by Singh, Armbya, and Singh [2010]: (1) normal, (2) gamma or approximate gamma, and then (3) lognormal. If a goodness-of-fit test indicated that one of these distributions was consistent with the measurement results, then the mean, standard deviation, and UCL95 were estimated assuming that distribution; otherwise, a goodness-of-fit test was performed for the next distribution in the sequence. If all three of these distributions were rejected, a nonparametric procedure was adopted. When some of the measurements were above their MDCs, and some of the measurements were below their MDCs, a similar strategy was followed, but using procedures that accommodate a data set with some less-than-detection results. The particular statistical formulae for estimating the mean, standard deviation, and UCL95 are documented by Singh, Armbya, and Singh [2010].

The composite sample data were generally found to be normally distributed by the goodnessof-fit tests and homogeneous across composite samples by the ANOVA tests. The estimates of the true mean and true standard deviation were obtained by the maximum likelihood method in all but one case when a distribution was identified as fitting the data, but the maximum likelihood estimates failed to converge properly.

The data contained potential outliers for several analytes. In data sets with potential outliers, the estimates were provided in the Appendix B summary tables with and without the outlier value in the data set. It is generally recommended to use the results without the outlier.

The selection of an appropriate form of UCL95 followed the guidelines of Singh, Armbya, and Singh [2010], except when the 95\% KM (BCA) form ${ }^{4}$ of UCL95 was suggested by those guidelines. In the judgment of the author of this report, the number of measurements in the data set was too small to support this (bootstrap) form of confidence limit. The $95 \% \mathrm{KM}$ (Chebyshev) form of UCL95 was used instead of the 95\% KM (BCA) form of UCL. This Chebyshev form of UCL95 is more conservative (generally higher in value) than the $95 \%$ KM (BCA) for of UCL95.

\footnotetext{
${ }^{4}$ The KM (BCA) confidence interval is described by Singh, Armbya, and Singh [2010]. It is a bias-corrected accelerated (BCA) form of bootstrap confidence interval using Kaplan-Meier estimates.
} 


\section{$6 \quad$ References}

[2011] Dean, B. "Tank 5 Composite Samples Volumetric Proportions," Savannah River Remediation LLC SRR-CDWA-2011-00067, Rev. 1 (April 20, 2011).

[2012] Oji, L.N.; Diprete, D.; Coleman, C.J.; and Hays, M.S. "Analysis of the Tank 5F Final Characterization Samples-2011 (U)," Savannah River National Laboratory Report SRNL-STI2012-00034, Rev. 0 (January 2012).

[2010] SAS Institute. Basic Analysis and Graphing, JMP 9.0.0 On-line Help Books, Cary, NC.

[2011] Shine, E.P. "Technical Review of the Method of Constructing Composite Samples with Uncertain volumetric Proportions," SRNL-STI-2011-00323 (May 24, 2011).

[1997] Singh, A.K.; Singh, A; and Englehardt, M. "The Lognormal Distribution in Environmental Applications," EPA/600/S-97/006 (December 1997).

[2010] Singh, A.; Armbya, N.; and Singh, A.K. "ProUCL Version 4.100 Technical Guide (Draft)" US EPA/600/R-07/041 (May 2010). 


\section{Appendix A.}

Measurement Results from the SRNL Analytical Laboratory

Table A1. Composite Sample Bulk Density (g/mL)

\begin{tabular}{|c|c|c|c|c|c|c|c|c|c|}
\hline Sample Bulk & \multicolumn{3}{|c|}{ Composite Sample 1} & \multicolumn{3}{|c|}{ Composite Sample 2} & \multicolumn{3}{|c|}{ Composite Sample 3} \\
\hline Density & 1.40 & 1.40 & 1.43 & 1.37 & 1.32 & 1.32 & 1.30 & 1.31 & 1.32 \\
\hline
\end{tabular}

Table A2. Radionuclides with All Measurements ( $\mu \mathrm{Ci} / \mathrm{g}$ ) above their Minimum Detectable Concentrations

\begin{tabular}{|c|c|c|c|c|c|c|c|c|c|}
\hline Analyte & \multicolumn{3}{|c|}{ Composite Sample 1} & \multicolumn{3}{|c|}{ Composite Sample 2} & \multicolumn{3}{|c|}{ Composite Sample 3} \\
\hline Am-241 & $7.30 \mathrm{E}+01$ & $6.53 E+01$ & $6.40 E+01$ & $7.12 \mathrm{E}+01$ & $6.35 \mathrm{E}+01$ & $7.16 \mathrm{E}+01$ & $7.34 \mathrm{E}+01$ & $7.70 E+01$ & $7.12 \mathrm{E}+01$ \\
\hline$A m-242 m$ & $1.77 \mathrm{E}-01$ & $1.70 \mathrm{E}-01$ & $1.41 \mathrm{E}-01$ & $1.90 \mathrm{E}-01$ & 1.27E-01 & $1.73 \mathrm{E}-01$ & $1.90 \mathrm{E}-01$ & $1.42 \mathrm{E}-01$ & NA \\
\hline Am-243 & $5.45 \mathrm{E}-01$ & 5.09E-01 & 4.77E-01 & $5.54 \mathrm{E}-01$ & 4.77E-01 & $5.72 \mathrm{E}-01$ & $5.54 \mathrm{E}-01$ & $5.63 \mathrm{E}-01$ & NA \\
\hline Ba-137m & $4.23 E+02$ & $3.51 E+02$ & $3.30 E+02$ & $4.30 \mathrm{E}+02$ & $3.34 \mathrm{E}+02$ & $4.12 E+02$ & $4.34 \mathrm{E}+02$ & $4.51 \mathrm{E}+02$ & $3.64 \mathrm{E}+02$ \\
\hline $\mathrm{Cm}-242$ & $1.47 \mathrm{E}-01$ & $1.41 \mathrm{E}-01$ & $1.17 \mathrm{E}-01$ & $1.57 \mathrm{E}-01$ & $1.05 \mathrm{E}-01$ & $1.43 \mathrm{E}-01$ & $1.57 \mathrm{E}-01$ & $1.18 \mathrm{E}-01$ & NA \\
\hline $\mathrm{Cm}-244$ & $3.32 \mathrm{E}+00$ & $2.98 \mathrm{E}+00$ & $3.59 \mathrm{E}+00$ & $2.93 E+00$ & $2.57 \mathrm{E}+00$ & $2.88 \mathrm{E}+00$ & $2.99 \mathrm{E}+00$ & $3.04 \mathrm{E}+00$ & NA \\
\hline Co-60 & $7.25 \mathrm{E}+00$ & $6.62 \mathrm{E}+00$ & $6.22 \mathrm{E}+00$ & $6.85 \mathrm{E}+00$ & $6.04 \mathrm{E}+00$ & $6.94 \mathrm{E}+00$ & $7.16 \mathrm{E}+00$ & $7.30 \mathrm{E}+00$ & $6.89 \mathrm{E}+00$ \\
\hline Cs-135 & $2.34 \mathrm{E}-03$ & $1.86 \mathrm{E}-03$ & $1.67 \mathrm{E}-03$ & $2.58 \mathrm{E}-03$ & $1.70 \mathrm{E}-03$ & $2.23 \mathrm{E}-03$ & $2.13 \mathrm{E}-03$ & $2.44 \mathrm{E}-03$ & $2.09 E-03$ \\
\hline Cs-137 & $4.47 E+02$ & $3.71 E+02$ & $3.49 E+02$ & $4.55 \mathrm{E}+02$ & $3.53 \mathrm{E}+02$ & $4.35 \mathrm{E}+02$ & $4.59 \mathrm{E}+02$ & $4.77 \mathrm{E}+02$ & $3.85 E+02$ \\
\hline Eu-154 & $3.00 E+01$ & $2.87 E+01$ & $2.85 E+01$ & $2.98 \mathrm{E}+01$ & $2.73 E+01$ & $2.93 E+01$ & $3.15 E+01$ & $3.14 \mathrm{E}+01$ & $3.22 \mathrm{E}+01$ \\
\hline Eu-155 & $3.77 E+00$ & $5.32 \mathrm{E}+00$ & $4.32 E+00$ & $3.79 \mathrm{E}+00$ & $4.36 \mathrm{E}+00$ & $4.33 E+00$ & $7.12 \mathrm{E}+00$ & $6.71 \mathrm{E}+00$ & $5.95 \mathrm{E}+00$ \\
\hline $\mathrm{Ni}-59$ & $4.73 E+00$ & $7.84 \mathrm{E}+00$ & $6.67 E+00$ & $5.18 \mathrm{E}+00$ & $5.72 \mathrm{E}+00$ & $4.50 \mathrm{E}+00$ & $5.14 \mathrm{E}+00$ & $3.82 \mathrm{E}+00$ & $6.04 \mathrm{E}+00$ \\
\hline $\mathrm{Ni}-63$ & $2.65 E+02$ & $3.01 E+02$ & $3.50 E+02$ & $2.18 \mathrm{E}+02$ & $2.33 \mathrm{E}+02$ & $2.10 \mathrm{E}+02$ & $3.34 \mathrm{E}+02$ & $4.64 \mathrm{E}+02$ & $2.98 \mathrm{E}+02$ \\
\hline Non-volatile beta & $2.95 E+04$ & $2.98 E+04$ & $3.05 E+04$ & $3.24 \mathrm{E}+04$ & $2.98 \mathrm{E}+04$ & $3.12 E+04$ & $2.85 E+04$ & $2.78 \mathrm{E}+04$ & $2.76 \mathrm{E}+04$ \\
\hline $\mathrm{Np}-237$ & $2.41 \mathrm{E}-02$ & $2.51 \mathrm{E}-02$ & $1.12 \mathrm{E}-02$ & $1.19 \mathrm{E}-02$ & $2.66 \mathrm{E}-02$ & $3.22 \mathrm{E}-02$ & $2.78 \mathrm{E}-02$ & $2.54 \mathrm{E}-02$ & $2.34 \mathrm{E}-02$ \\
\hline
\end{tabular}

NA indicates not analyzed.

Table A2 Continued on Next Page 


\section{Appendix A}

\section{Measurement Results from the SRNL Analytical Laboratory}

Table A2 Continued. Radionuclides with All Measurements ( $\mu \mathrm{Ci} / \mathrm{g}$ ) above their Minimum Detectable Concentrations

\begin{tabular}{|c|c|c|c|c|c|c|c|c|c|}
\hline \multirow{2}{*}{$\begin{array}{l}\text { Analyte } \\
\mathrm{Pd}-107\end{array}$} & \multicolumn{3}{|c|}{ Composite Sample 1} & \multicolumn{3}{|c|}{ Composite Sample 2} & \multicolumn{3}{|c|}{ Composite Sample 3} \\
\hline & $2.50 \mathrm{E}-03$ & $2.51 \mathrm{E}-03$ & $2.81 \mathrm{E}-03$ & $6.12 \mathrm{E}-03$ & $2.21 \mathrm{E}-03$ & 8.04E-03 & $3.46 \mathrm{E}-03$ & $2.62 \mathrm{E}-03$ & $3.55 \mathrm{E}-03$ \\
\hline $\mathrm{Pu}-238$ & $2.89 \mathrm{E}+00$ & $2.51 \mathrm{E}+00$ & $2.28 \mathrm{E}+00$ & $2.40 \mathrm{E}+00$ & $2.24 \mathrm{E}+00$ & $2.58 \mathrm{E}+00$ & $2.68 \mathrm{E}+00$ & $3.07 E+00$ & $2.63 E+00$ \\
\hline Pu-239 & $8.80 \mathrm{E}+00$ & $8.47 \mathrm{E}+00$ & $7.25 \mathrm{E}+00$ & $8.12 \mathrm{E}+00$ & $6.21 E+00$ & $8.83 E+00$ & $8.80 \mathrm{E}+00$ & $9.11 \mathrm{E}+00$ & $8.42 E+00$ \\
\hline $\mathrm{Pu}-239 / 240$ & $1.09 \mathrm{E}+01$ & $1.05 \mathrm{E}+01$ & $8.92 \mathrm{E}+00$ & $1.00 \mathrm{E}+01$ & $7.66 \mathrm{E}+00$ & $1.09 \mathrm{E}+01$ & $1.09 \mathrm{E}+01$ & $1.13 \mathrm{E}+01$ & $1.04 \mathrm{E}+01$ \\
\hline $\mathrm{Pu}-240$ & $2.05 \mathrm{E}+00$ & $1.97 \mathrm{E}+00$ & $1.68 \mathrm{E}+00$ & $1.88 \mathrm{E}+00$ & $1.47 \mathrm{E}+00$ & $2.08 \mathrm{E}+00$ & $2.06 \mathrm{E}+00$ & $2.14 \mathrm{E}+00$ & $1.97 \mathrm{E}+00$ \\
\hline $\mathrm{Pu}-242$ & $3.97 \mathrm{E}-04$ & $4.24 \mathrm{E}-04$ & $3.41 \mathrm{E}-04$ & $3.32 \mathrm{E}-04$ & $2.70 \mathrm{E}-04$ & $3.95 \mathrm{E}-04$ & $4.28 \mathrm{E}-04$ & $4.21 \mathrm{E}-04$ & 3.83E-04 \\
\hline Se-79 & $1.33 \mathrm{E}-02$ & 8.29E-03 & $1.42 \mathrm{E}-02$ & $5.86 \mathrm{E}-03$ & $3.17 \mathrm{E}-03$ & $1.85 \mathrm{E}-02$ & $5.05 \mathrm{E}-03$ & $1.18 \mathrm{E}-02$ & $1.18 \mathrm{E}-02$ \\
\hline Sm-151 & $7.16 \mathrm{E}+02$ & $7.25 \mathrm{E}+02$ & $8.02 \mathrm{E}+02$ & $7.88 \mathrm{E}+02$ & $7.07 E+02$ & $7.57 \mathrm{E}+02$ & $8.51 \mathrm{E}+02$ & $8.38 \mathrm{E}+02$ & $8.29 E+02$ \\
\hline Sr-90 & $1.21 \mathrm{E}+04$ & $1.19 \mathrm{E}+04$ & $1.23 \mathrm{E}+04$ & $1.28 \mathrm{E}+04$ & $1.25 \mathrm{E}+04$ & $1.23 \mathrm{E}+04$ & $1.17 \mathrm{E}+04$ & $1.03 \mathrm{E}+04$ & $1.25 \mathrm{E}+04$ \\
\hline Tc-99 & $1.02 \mathrm{E}-02$ & $7.66 \mathrm{E}-03$ & 8.47E-03 & $1.06 \mathrm{E}-02$ & $9.64 \mathrm{E}-03$ & $1.26 \mathrm{E}-02$ & 1.07E-02 & $9.10 \mathrm{E}-03$ & $1.11 \mathrm{E}-02$ \\
\hline Th-230 & $1.63 \mathrm{E}-03$ & $1.56 \mathrm{E}-03$ & $2.16 \mathrm{E}-03$ & 5.99E-04 & $2.31 \mathrm{E}-03$ & $3.50 \mathrm{E}-04$ & $5.72 \mathrm{E}-04$ & $9.19 \mathrm{E}-04$ & $3.88 \mathrm{E}-03$ \\
\hline U-235 & $1.80 \mathrm{E}-04$ & $1.78 \mathrm{E}-04$ & $1.60 \mathrm{E}-04$ & $2.33 \mathrm{E}-04$ & $1.87 \mathrm{E}-04$ & $2.25 \mathrm{E}-04$ & $2.09 \mathrm{E}-04$ & $2.08 \mathrm{E}-04$ & $1.96 \mathrm{E}-04$ \\
\hline U-236 & $2.25 \mathrm{E}-04$ & $2.24 \mathrm{E}-04$ & $1.95 \mathrm{E}-04$ & $2.85 \mathrm{E}-04$ & 2.29E-04 & $2.70 \mathrm{E}-04$ & $2.59 \mathrm{E}-04$ & $2.55 \mathrm{E}-04$ & $2.36 \mathrm{E}-04$ \\
\hline U-238 & 4.19E-03 & $4.10 \mathrm{E}-03$ & $3.65 \mathrm{E}-03$ & $5.33 \mathrm{E}-03$ & $4.31 \mathrm{E}-03$ & $5.29 E-03$ & $4.86 \mathrm{E}-03$ & $4.82 \mathrm{E}-03$ & 4.50E-03 \\
\hline Y-90 & $1.21 \mathrm{E}+04$ & $1.19 \mathrm{E}+04$ & $1.23 \mathrm{E}+04$ & $1.28 \mathrm{E}+04$ & $1.25 \mathrm{E}+04$ & $1.23 \mathrm{E}+04$ & $1.17 \mathrm{E}+04$ & $1.03 \mathrm{E}+04$ & $1.25 \mathrm{E}+04$ \\
\hline$Z r-93$ & $3.15 \mathrm{E}+00$ & $3.18 \mathrm{E}+00$ & $2.49 \mathrm{E}+00$ & $3.12 \mathrm{E}+00$ & $2.70 \mathrm{E}+00$ & $2.83 \mathrm{E}+00$ & $3.07 \mathrm{E}+00$ & $3.08 \mathrm{E}+00$ & $3.25 \mathrm{E}+00$ \\
\hline
\end{tabular}




\section{Appendix A}

\section{Measurement Results from the SRNL Analytical Laboratory}

Table A3. Radionuclides with All Measurements ( $\mu \mathrm{Ci} / \mathrm{g}$ ) below their Minimum Detectable Concentrations*

\begin{tabular}{|c|c|c|c|c|c|c|c|c|c|}
\hline \multirow{2}{*}{$\begin{array}{l}\text { Analyte } \\
\text { Ac-227 }\end{array}$} & \multicolumn{3}{|c|}{ Composite Sample 1} & \multicolumn{3}{|c|}{ Composite Sample 2} & \multicolumn{3}{|c|}{ Composite Sample 3} \\
\hline & NA & NA & $<5.23 \mathrm{E}-04$ & NA & NA & $<9.50 \mathrm{E}-05$ & NA & NA & $<1.65 \mathrm{E}-04$ \\
\hline $\mathrm{Al}-26$ & NA & NA & $<1.29 \mathrm{E}-02$ & NA & NA & $<1.31 \mathrm{E}-02$ & NA & NA & $<1.94 \mathrm{E}-02$ \\
\hline $\mathrm{Bk}-247$ & $<5.23 \mathrm{E}-03$ & $<4.09 E-03$ & $<1.64 \mathrm{E}-03$ & $<3.13 \mathrm{E}-03$ & $<1.94 \mathrm{E}-03$ & $<1.15 \mathrm{E}-03$ & $<5.99 \mathrm{E}-03$ & $<1.13 \mathrm{E}-03$ & NA \\
\hline $\mathrm{C}-14$ & $<8.33 \mathrm{E}-04$ & $<8.51 \mathrm{E}-04$ & $<7.39 \mathrm{E}-04$ & $<7.39 \mathrm{E}-04$ & $<1.58 \mathrm{E}-03$ & $<1.58 \mathrm{E}-03$ & $<3.30 \mathrm{E}-03$ & $<3.40 \mathrm{E}-03$ & $<7.52 \mathrm{E}-04$ \\
\hline Cf-249 & $<1.78 \mathrm{E}-02$ & $<1.36 \mathrm{E}-02$ & $<7.39 \mathrm{E}-03$ & $<1.19 \mathrm{E}-02$ & $<1.13 \mathrm{E}-02$ & $<7.75 \mathrm{E}-03$ & $<1.88 \mathrm{E}-02$ & $<7.93 \mathrm{E}-03$ & NA \\
\hline Cf-250 & $<8.29 \mathrm{E}-04$ & $<7.61 \mathrm{E}-04$ & $<2.24 \mathrm{E}-04$ & $<3.46 \mathrm{E}-04$ & $<3.68 \mathrm{E}-04$ & $<1.52 \mathrm{E}-04$ & $<1.02 \mathrm{E}-03$ & $<2.23 \mathrm{E}-04$ & NA \\
\hline Cf-251 & $<4.82 \mathrm{E}-02$ & $<3.66 \mathrm{E}-02$ & $<1.99 \mathrm{E}-02$ & $<3.18 \mathrm{E}-02$ & $<3.00 \mathrm{E}-02$ & $<1.65 \mathrm{E}-02$ & $<5.05 \mathrm{E}-02$ & $<2.11 \mathrm{E}-02$ & NA \\
\hline Cf-252 & $<1.47 \mathrm{E}-01$ & $<1.41 \mathrm{E}-01$ & $<1.17 \mathrm{E}-01$ & $<1.57 \mathrm{E}-01$ & $<1.05 \mathrm{E}-01$ & $<1.43 \mathrm{E}-01$ & $<1.57 \mathrm{E}-01$ & $<1.18 \mathrm{E}-01$ & NA \\
\hline $\mathrm{Cl}-36$ & NA & NA & $<2.87 \mathrm{E}-03$ & NA & NA & $<5.05 E-03$ & NA & NA & $<8.42 \mathrm{E}-03$ \\
\hline $\mathrm{Cm}-243$ & $<7.52 \mathrm{E}-02$ & $<5.77 \mathrm{E}-02$ & $<4.36 \mathrm{E}-01$ & $<5.36 \mathrm{E}-01$ & $<4.64 \mathrm{E}-01$ & $<3.31 \mathrm{E}-01$ & $<5.68 \mathrm{E}-01$ & $<5.00 \mathrm{E}-01$ & $<1.40 \mathrm{E}+00$ \\
\hline $\mathrm{Cm}-245$ & $<1.45 \mathrm{E}-03$ & $<1.35 \mathrm{E}-03$ & $<7.03 \mathrm{E}-04$ & $<7.70 \mathrm{E}-04$ & $<6.22 \mathrm{E}-04$ & $<5.63 \mathrm{E}-04$ & $<1.50 \mathrm{E}-03$ & $<7.34 \mathrm{E}-04$ & NA \\
\hline $\mathrm{Cm}-246$ & $<2.09 \mathrm{E}-03$ & $<2.39 \mathrm{E}-03$ & $<1.24 \mathrm{E}-03$ & $<1.98 \mathrm{E}-03$ & $<1.04 \mathrm{E}-03$ & $<1.11 \mathrm{E}-03$ & $<3.22 \mathrm{E}-03$ & $<1.24 \mathrm{E}-03$ & NA \\
\hline $\mathrm{Cm}-247$ & $<4.68 \mathrm{E}-07$ & $<3.67 \mathrm{E}-07$ & $<1.47 \mathrm{E}-07$ & $<2.81 \mathrm{E}-07$ & $<1.74 \mathrm{E}-07$ & $<1.03 E-07$ & $<5.41 \mathrm{E}-07$ & $<1.01 \mathrm{E}-07$ & NA \\
\hline $\mathrm{Cm}-248$ & $<5.72 \mathrm{E}-05$ & $<3.43 \mathrm{E}-05$ & $<1.45 \mathrm{E}-05$ & $<3.96 \mathrm{E}-05$ & $<1.93 \mathrm{E}-05$ & $<1.32 \mathrm{E}-05$ & $<5.36 \mathrm{E}-05$ & $<1.39 \mathrm{E}-05$ & NA \\
\hline Eu-152 & NA & NA & $<2.11 \mathrm{E}-01$ & NA & NA & $<1.47 \mathrm{E}-01$ & NA & NA & $<2.11 \mathrm{E}-01$ \\
\hline Gross alpha & $<3.23 \mathrm{E}+02$ & $<4.91 \mathrm{E}+02$ & $<4.20 \mathrm{E}+02$ & $<3.09 \mathrm{E}+02$ & $<3.48 \mathrm{E}+02$ & $<1.07 \mathrm{E}+03$ & $<2.09 \mathrm{E}+02$ & $<6.58 \mathrm{E}+02$ & $<3.68 \mathrm{E}+02$ \\
\hline $\mathrm{H}-3$ & $<8.65 \mathrm{E}-03$ & $<1.01 \mathrm{E}-02$ & $<9.09 \mathrm{E}-03$ & $<1.00 \mathrm{E}-02$ & $<8.37 \mathrm{E}-03$ & $<1.72 \mathrm{E}-02$ & $<9.28 \mathrm{E}-03$ & $<9.53 \mathrm{E}-03$ & $<1.83 \mathrm{E}-02$ \\
\hline $\mathrm{K}-40$ & NA & NA & $<5.14 \mathrm{E}-03$ & NA & NA & $<3.71 \mathrm{E}-03$ & NA & NA & $<8.24 \mathrm{E}-04$ \\
\hline $\mathrm{Nb}-94$ & NA & NA & $<2.87 \mathrm{E}-03$ & NA & NA & $<2.11 \mathrm{E}-03$ & NA & NA & $<1.14 \mathrm{E}-03$ \\
\hline $\mathrm{Pa}-231$ & $<1.02 \mathrm{E}-03$ & $<2.14 \mathrm{E}-04$ & $<1.41 \mathrm{E}-04$ & $<2.35 \mathrm{E}-04$ & $<2.77 \mathrm{E}-04$ & $<2.53 \mathrm{E}-04$ & NA & $<3.01 \mathrm{E}-04$ & $<3.89 \mathrm{E}-04$ \\
\hline $\mathrm{Pm}-147$ & $<4.59 \mathrm{E}+02$ & $<5.45 \mathrm{E}+02$ & $<5.81 \mathrm{E}+02$ & $<5.95 \mathrm{E}+02$ & $<5.36 \mathrm{E}+02$ & $<5.63 E+02$ & $<6.40 \mathrm{E}+02$ & $<6.08 \mathrm{E}+02$ & $<6.22 \mathrm{E}+02$ \\
\hline Pt-193 & $<6.37 \mathrm{E}-04$ & $<6.95 \mathrm{E}-04$ & $<4.91 \mathrm{E}-04$ & NA & NA & $<4.24 \mathrm{E}-04$ & NA & NA & $<1.56 \mathrm{E}-03$ \\
\hline $\mathrm{Pu}-241$ & $<1.19 \mathrm{E}+01$ & $<1.19 \mathrm{E}+01$ & $<1.30 \mathrm{E}+01$ & $<1.37 \mathrm{E}+01$ & $<8.51 \mathrm{E}+00$ & $<8.69 \mathrm{E}+00$ & $<1.27 \mathrm{E}+01$ & $<1.28 \mathrm{E}+01$ & $<9.82 E+00$ \\
\hline Pu-244 & $<8.36 \mathrm{E}-07$ & $<1.05 \mathrm{E}-06$ & $<9.74 \mathrm{E}-07$ & $<1.17 \mathrm{E}-06$ & $<7.43 \mathrm{E}-07$ & $<9.46 \mathrm{E}-07$ & $<8.40 \mathrm{E}-07$ & $<1.12 \mathrm{E}-06$ & $<1.18 \mathrm{E}-06$ \\
\hline Ra-226 & NA & NA & $<9.78 \mathrm{E}-03$ & NA & NA & $<6.81 \mathrm{E}-04$ & NA & NA & $<2.44 \mathrm{E}-03$ \\
\hline
\end{tabular}

$<$ NUMBER indicates that the measured result is below the MDC equal to the NUMBER.

NA indicates not analyzed.

*While additional measurements were obtained for these isotopes, the results were selected from the method that gave the best detection limit as described in the TTQAP. While additional data was collected, only these primary values were assessed and tabulated for this analysis. 


\section{Appendix A}

\section{Measurement Results from the SRNL Analytical Lab}

Table A3 Continued. Radionuclides with All Measurements ( $\mu \mathrm{Ci} / \mathrm{g})$ below their Minimum Detectable Concentrations

\begin{tabular}{|c|c|c|c|c|c|c|c|c|c|}
\hline \multirow{2}{*}{$\begin{array}{l}\text { Analyte } \\
\text { Sb-126 }\end{array}$} & \multicolumn{3}{|c|}{ Composite Sample 1} & \multicolumn{3}{|c|}{ Composite Sample 2} & \multicolumn{3}{|c|}{ Composite Sample 3} \\
\hline & NA & NA & $<1.09 \mathrm{E}-01$ & NA & NA & $<1.04 \mathrm{E}-01$ & NA & NA & $<1.50 \mathrm{E}-01$ \\
\hline $\mathrm{Sb}-126 \mathrm{~m}$ & NA & NA & $<1.09 \mathrm{E}-01$ & NA & NA & $<1.04 \mathrm{E}-01$ & NA & NA & $<1.50 \mathrm{E}-01$ \\
\hline Sn-126 & NA & NA & $<8.06 \mathrm{E}-01$ & NA & NA & $<8.51 \mathrm{E}-01$ & NA & NA & $<1.18 \mathrm{E}+00$ \\
\hline U-232 & $<1.82 \mathrm{E}-05$ & $<1.94 \mathrm{E}-05$ & $<1.23 \mathrm{E}-05$ & $<1.59 \mathrm{E}-05$ & $<2.72 \mathrm{E}-05$ & $<3.47 \mathrm{E}-05$ & $<5.63 \mathrm{E}-06$ & $<4.62 \mathrm{E}-06$ & $<2.23 \mathrm{E}-05$ \\
\hline $\mathrm{U}-233$ & $<2.62 \mathrm{E}-04$ & $<2.64 \mathrm{E}-04$ & $<2.48 \mathrm{E}-04$ & $<2.52 \mathrm{E}-04$ & $<2.56 \mathrm{E}-04$ & $<7.58 \mathrm{E}-03$ & $<2.49 \mathrm{E}-04$ & $<2.34 \mathrm{E}-04$ & $<2.65 \mathrm{E}-04$ \\
\hline
\end{tabular}

$<$ NUMBER indicates that the measured result is below the MDC equal to the NUMBER.

NA indicates not analyzed.

Table A4. Radionuclides with a Mixture of Measurements ( $\mu \mathrm{Ci} / \mathrm{g}$ ) above and below their Minimum Detectable Concentrations

\begin{tabular}{|l|c|c|c|c|c|c|c|c|c|}
\hline Analyte & \multicolumn{3}{|c|}{ Composite Sample 1 } & \multicolumn{3}{c|}{ Composite Sample 2 } & \multicolumn{3}{c|}{ Composite Sample 3 } \\
\hline I-129 & $1.10 \mathrm{E}-04$ & $1.98 \mathrm{E}-04$ & $1.64 \mathrm{E}-04$ & $1.36 \mathrm{E}-04$ & $<3.49 \mathrm{E}-03$ & $1.18 \mathrm{E}-03$ & $2.50 \mathrm{E}-04$ & $2.95 \mathrm{E}-04$ & $1.38 \mathrm{E}-04$ \\
\hline Th-229 & $2.95 \mathrm{E}-06$ & $4.10 \mathrm{E}-06$ & $2.38 \mathrm{E}-05$ & $3.77 \mathrm{E}-06$ & $6.67 \mathrm{E}-06$ & $8.11 \mathrm{E}-06$ & $<1.05 \mathrm{E}-06$ & $1.22 \mathrm{E}-06$ & $4.23 \mathrm{E}-05$ \\
\hline $\mathrm{U}-234$ & $4.27 \mathrm{E}-03$ & $4.08 \mathrm{E}-03$ & $3.54 \mathrm{E}-03$ & $5.33 \mathrm{E}-03$ & $4.32 \mathrm{E}-03$ & $<4.89 \mathrm{E}-03$ & $4.67 \mathrm{E}-03$ & $4.69 \mathrm{E}-03$ & $4.30 \mathrm{E}-03$ \\
\hline
\end{tabular}

$<$ NUMBER indicates that the measured result is below the MDC equal to the NUMBER. 


\section{Appendix A. Measurement Results from the SRNL Analytical Laboratory}

Table A5. Inorganics with All Measurements ( $\mathrm{mg} / \mathrm{g}$ ) above their Minimum Detectable Concentrations

\begin{tabular}{|c|c|c|c|c|c|c|c|c|c|}
\hline \multirow{2}{*}{$\begin{array}{l}\text { Analyte } \\
\mathrm{Ag}\end{array}$} & \multicolumn{3}{|c|}{ Composite Sample 1} & \multicolumn{3}{|c|}{ Composite Sample 2} & \multicolumn{3}{|c|}{ Composite Sample 3} \\
\hline & $2.01 \mathrm{E}-01$ & $2.38 \mathrm{E}-01$ & $2.73 \mathrm{E}-01$ & $2.16 \mathrm{E}-01$ & $2.15 \mathrm{E}-01$ & $2.16 \mathrm{E}-01$ & $2.82 \mathrm{E}-01$ & $2.76 \mathrm{E}-01$ & $2.95 \mathrm{E}-01$ \\
\hline $\mathrm{Al}$ & $4.06 \mathrm{E}+00$ & $4.42 E+00$ & $8.70 \mathrm{E}+00$ & $4.31 E+00$ & $4.45 E+00$ & $4.35 E+00$ & $4.58 \mathrm{E}+00$ & $4.14 \mathrm{E}+00$ & $4.59 E+00$ \\
\hline $\mathrm{B}$ & $1.40 \mathrm{E}+00$ & $1.30 \mathrm{E}+00$ & $1.20 \mathrm{E}+00$ & $1.40 \mathrm{E}+00$ & $1.37 \mathrm{E}+00$ & $1.35 \mathrm{E}+00$ & $1.27 \mathrm{E}+00$ & $1.19 \mathrm{E}+00$ & $1.25 \mathrm{E}+00$ \\
\hline $\mathrm{Ba}$ & $1.74 \mathrm{E}+00$ & $1.97 \mathrm{E}+00$ & $2.07 \mathrm{E}+00$ & $1.77 \mathrm{E}+00$ & $1.86 \mathrm{E}+00$ & $1.83 \mathrm{E}+00$ & $2.10 \mathrm{E}+00$ & $2.01 \mathrm{E}+00$ & $2.10 \mathrm{E}+00$ \\
\hline $\mathrm{Be}$ & $1.30 \mathrm{E}-02$ & $1.21 \mathrm{E}-02$ & $1.12 \mathrm{E}-02$ & $1.29 \mathrm{E}-02$ & $1.27 \mathrm{E}-02$ & $1.26 \mathrm{E}-02$ & $1.16 \mathrm{E}-02$ & $1.11 \mathrm{E}-02$ & 1.17E-02 \\
\hline $\mathrm{Ca}$ & $1.43 \mathrm{E}+00$ & $1.38 \mathrm{E}+00$ & $1.43 \mathrm{E}+00$ & $1.55 \mathrm{E}+00$ & $1.56 \mathrm{E}+00$ & $1.55 \mathrm{E}+00$ & $1.81 \mathrm{E}+00$ & $1.38 \mathrm{E}+00$ & $1.75 \mathrm{E}+00$ \\
\hline $\mathrm{Cd}$ & $8.13 \mathrm{E}-02$ & $9.16 \mathrm{E}-02$ & $9.69 \mathrm{E}-02$ & $8.33 \mathrm{E}-02$ & $8.73 \mathrm{E}-02$ & 8.59E-02 & $9.28 \mathrm{E}-02$ & $8.93 \mathrm{E}-02$ & $9.56 \mathrm{E}-02$ \\
\hline $\mathrm{Ce}$ & $1.97 \mathrm{E}+00$ & $2.59 \mathrm{E}+00$ & $3.06 \mathrm{E}+00$ & $1.92 \mathrm{E}+00$ & $2.29 \mathrm{E}+00$ & $2.18 \mathrm{E}+00$ & $2.96 \mathrm{E}+00$ & $2.86 \mathrm{E}+00$ & $3.07 E+00$ \\
\hline Co & $1.87 \mathrm{E}-01$ & $2.12 \mathrm{E}-01$ & $2.39 \mathrm{E}-01$ & $1.86 \mathrm{E}-01$ & $1.96 \mathrm{E}-01$ & $1.95 \mathrm{E}-01$ & $2.40 \mathrm{E}-01$ & $2.30 \mathrm{E}-01$ & 2.40E-01 \\
\hline $\mathrm{Cr}$ & $1.39 \mathrm{E}+00$ & $1.04 \mathrm{E}+00$ & $9.68 \mathrm{E}-01$ & $9.82 \mathrm{E}-01$ & $9.98 \mathrm{E}-01$ & $9.78 \mathrm{E}-01$ & $1.03 \mathrm{E}+00$ & $1.01 \mathrm{E}+00$ & $1.06 \mathrm{E}+00$ \\
\hline $\mathrm{Cu}$ & $6.84 \mathrm{E}-01$ & $7.16 \mathrm{E}-01$ & $7.60 \mathrm{E}-01$ & $6.42 \mathrm{E}-01$ & $6.68 \mathrm{E}-01$ & $6.59 E-01$ & $9.54 \mathrm{E}-01$ & $6.59 \mathrm{E}-01$ & 7.42E-01 \\
\hline $\mathrm{Fe}$ & $5.23 \mathrm{E}+02$ & $4.88 \mathrm{E}+02$ & $4.52 E+02$ & $5.22 \mathrm{E}+02$ & $5.15 \mathrm{E}+02$ & $5.05 E+02$ & $4.66 \mathrm{E}+02$ & $4.44 \mathrm{E}+02$ & $4.65 E+02$ \\
\hline $\mathrm{Gd}$ & $1.93 \mathrm{E}-01$ & $1.93 \mathrm{E}-01$ & $1.93 \mathrm{E}-01$ & $1.93 \mathrm{E}-01$ & $1.96 \mathrm{E}-01$ & $1.95 \mathrm{E}-01$ & $2.04 \mathrm{E}-01$ & $1.92 \mathrm{E}-01$ & 2.02E-01 \\
\hline $\mathrm{Hg}$ & $1.84 \mathrm{E}+00$ & $2.32 \mathrm{E}+00$ & $2.55 \mathrm{E}+00$ & $1.92 \mathrm{E}+00$ & $2.07 \mathrm{E}+00$ & $1.98 \mathrm{E}+00$ & $2.49 E+00$ & $2.53 \mathrm{E}+00$ & $2.61 \mathrm{E}+00$ \\
\hline $\mathrm{K}$ & $2.94 \mathrm{E}-01$ & $3.68 \mathrm{E}-01$ & $3.64 \mathrm{E}-01$ & $2.93 \mathrm{E}-01$ & $2.47 \mathrm{E}-01$ & $2.68 \mathrm{E}-01$ & 3.39E-01 & $2.55 \mathrm{E}-01$ & $4.40 \mathrm{E}-01$ \\
\hline La & $1.33 \mathrm{E}+00$ & $1.38 \mathrm{E}+00$ & $1.45 \mathrm{E}+00$ & $1.21 \mathrm{E}+00$ & $1.29 \mathrm{E}+00$ & $1.26 \mathrm{E}+00$ & $1.65 \mathrm{E}+00$ & $1.56 \mathrm{E}+00$ & $1.65 \mathrm{E}+00$ \\
\hline $\mathrm{Li}$ & 4.00E-01 & $5.30 \mathrm{E}-01$ & $6.09 \mathrm{E}-01$ & $4.15 \mathrm{E}-01$ & 4.79E-01 & $4.55 \mathrm{E}-01$ & 5.57E-01 & $5.51 \mathrm{E}-01$ & 5.87E-01 \\
\hline $\mathrm{Mg}$ & 4.54E-01 & $4.88 \mathrm{E}-01$ & $5.27 \mathrm{E}-01$ & 4.70E-01 & 4.87E-01 & 4.80E-01 & $5.15 \mathrm{E}-01$ & 4.73E-01 & 5.10E-01 \\
\hline $\mathrm{Mn}$ & $3.11 \mathrm{E}+01$ & $3.43 \mathrm{E}+01$ & $3.80 \mathrm{E}+01$ & $3.05 \mathrm{E}+01$ & $3.14 \mathrm{E}+01$ & $3.18 \mathrm{E}+01$ & $3.68 \mathrm{E}+01$ & $3.37 \mathrm{E}+01$ & $3.54 \mathrm{E}+01$ \\
\hline Mo & 4.87E-02 & $5.10 \mathrm{E}-02$ & $5.06 \mathrm{E}-02$ & $4.55 \mathrm{E}-02$ & $4.42 \mathrm{E}-02$ & $4.56 \mathrm{E}-02$ & 4.57E-02 & $4.34 \mathrm{E}-02$ & 4.49E-02 \\
\hline $\mathrm{Na}$ & $3.60 \mathrm{E}+00$ & $3.55 \mathrm{E}+00$ & $3.61 \mathrm{E}+00$ & $3.60 E+00$ & $3.71 \mathrm{E}+00$ & $3.71 E+00$ & $4.23 E+00$ & $3.88 \mathrm{E}+00$ & $4.11 \mathrm{E}+00$ \\
\hline $\mathrm{Ni}$ & $4.54 \mathrm{E}+01$ & $5.63 E+01$ & $6.34 \mathrm{E}+01$ & $4.63 E+01$ & $5.17 \mathrm{E}+01$ & $4.99 E+01$ & $6.11 E+01$ & $5.95 \mathrm{E}+01$ & $6.32 \mathrm{E}+01$ \\
\hline $\mathrm{P}$ & $2.26 \mathrm{E}-01$ & $2.11 \mathrm{E}-01$ & $2.65 \mathrm{E}-01$ & $2.19 \mathrm{E}-01$ & $3.21 \mathrm{E}-01$ & 3.34E-01 & $2.95 \mathrm{E}-01$ & $2.88 \mathrm{E}-01$ & 2.94E-01 \\
\hline $\mathrm{Pb}$ & $3.88 \mathrm{E}+00$ & $3.70 \mathrm{E}+00$ & $3.49 \mathrm{E}+00$ & $3.85 \mathrm{E}+00$ & $3.78 \mathrm{E}+00$ & $3.77 E+00$ & $3.58 \mathrm{E}+00$ & $3.43 E+00$ & $3.62 E+00$ \\
\hline $\mathrm{Si}$ & $1.05 \mathrm{E}+00$ & $1.05 \mathrm{E}+00$ & 6.04E-01 & $1.24 \mathrm{E}+00$ & $1.32 \mathrm{E}+00$ & $9.13 \mathrm{E}-01$ & 7.99E-01 & $1.77 \mathrm{E}+00$ & $1.15 \mathrm{E}+00$ \\
\hline $\mathrm{Sn}$ & 4.37E-02 & $5.06 \mathrm{E}-02$ & $3.18 \mathrm{E}-02$ & $4.41 \mathrm{E}-02$ & $4.08 \mathrm{E}-02$ & $4.40 \mathrm{E}-02$ & $3.70 \mathrm{E}-02$ & $3.86 \mathrm{E}-02$ & $4.12 \mathrm{E}-02$ \\
\hline $\mathrm{Sr}$ & $4.11 \mathrm{E}-01$ & 3.81E-01 & $3.65 \mathrm{E}-01$ & $4.11 \mathrm{E}-01$ & $4.03 \mathrm{E}-01$ & 4.01E-01 & $3.53 \mathrm{E}-01$ & 3.31E-01 & $3.46 \mathrm{E}-01$ \\
\hline $\mathrm{Ti}$ & $2.22 \mathrm{E}-01$ & $2.55 \mathrm{E}-01$ & $2.79 \mathrm{E}-01$ & $2.30 \mathrm{E}-01$ & $2.45 \mathrm{E}-01$ & $2.46 \mathrm{E}-01$ & $2.54 \mathrm{E}-01$ & $2.46 \mathrm{E}-01$ & $2.66 \mathrm{E}-01$ \\
\hline$U$ & $7.14 \mathrm{E}+00$ & $8.13 E+00$ & $9.23 E+00$ & $7.97 \mathrm{E}+00$ & $8.89 E+00$ & $9.43 E+00$ & $1.06 \mathrm{E}+01$ & $9.33 \mathrm{E}+00$ & $9.64 \mathrm{E}+00$ \\
\hline $\mathrm{Zn}$ & $3.70 \mathrm{E}-01$ & 4.11E-01 & $5.12 \mathrm{E}-01$ & $3.62 \mathrm{E}-01$ & $3.81 \mathrm{E}-01$ & $3.80 \mathrm{E}-01$ & $6.61 \mathrm{E}-01$ & $4.22 \mathrm{E}-01$ & 5.03E-01 \\
\hline $\mathrm{Zr}$ & $3.54 \mathrm{E}+00$ & $4.43 E+00$ & $4.57 \mathrm{E}+00$ & $3.74 \mathrm{E}+00$ & $4.07 \mathrm{E}+00$ & $3.98 \mathrm{E}+00$ & $4.58 \mathrm{E}+00$ & $4.69 E+00$ & $4.93 E+00$ \\
\hline
\end{tabular}




\section{Appendix A}

\section{Measurement Results from the SRNL Analytical Laboratory}

Table A6. Inorganics with All Measurements ( $\mathrm{mg} / \mathrm{g}$ ) below their Minimum Detectable Concentrations

\begin{tabular}{|c|c|c|c|c|c|c|c|c|c|}
\hline Analyte & \multicolumn{3}{|c|}{ Composite Sample 1} & \multicolumn{3}{|c|}{ Composite Sample 2} & \multicolumn{3}{|c|}{ Composite Sample 3} \\
\hline As & $<9.44 \mathrm{E}-03$ & $<1.07 \mathrm{E}-02$ & $<9.60 \mathrm{E}-03$ & $<1.06 \mathrm{E}-02$ & $<9.91 \mathrm{E}-03$ & $<1.04 \mathrm{E}-02$ & $<9.79 E-03$ & $<1.04 \mathrm{E}-02$ & $<1.05 \mathrm{E}-02$ \\
\hline $\mathrm{Sb}$ & $<7.67 \mathrm{E}-01$ & $<8.68 \mathrm{E}-01$ & $<7.80 \mathrm{E}-01$ & $<8.60 \mathrm{E}-01$ & $<8.00 \mathrm{E}-01$ & $<8.40 \mathrm{E}-01$ & $<8.00 \mathrm{E}-01$ & $<8.10 \mathrm{E}-01$ & $<8.50 \mathrm{E}-01$ \\
\hline Se & $<2.00 \mathrm{E}-02$ & $<2.00 \mathrm{E}-02$ & $<2.00 \mathrm{E}-02$ & $<2.10 \mathrm{E}-02$ & $<2.00 \mathrm{E}-03$ & $<2.00 \mathrm{E}-03$ & $<2.00 \mathrm{E}-02$ & $<2.10 \mathrm{E}-02$ & $<2.10 \mathrm{E}-02$ \\
\hline Th & $<3.90 \mathrm{E}-01$ & $<4.40 \mathrm{E}-01$ & $<3.90 \mathrm{E}-01$ & $<4.30 \mathrm{E}-01$ & $<4.00 \mathrm{E}-01$ & $<4.20 \mathrm{E}-01$ & $<4.00 \mathrm{E}-01$ & $<4.00 \mathrm{E}-01$ & $<4.30 \mathrm{E}-01$ \\
\hline V & $<3.40 \mathrm{E}-02$ & $<3.80 \mathrm{E}-02$ & $<3.40 \mathrm{E}-02$ & $<3.80 \mathrm{E}-02$ & $<3.60 \mathrm{E}-02$ & $<3.70 \mathrm{E}-02$ & $<4.00 \mathrm{E}-02$ & $<4.00 \mathrm{E}-02$ & $<4.00 \mathrm{E}-02$ \\
\hline
\end{tabular}

$<$ NUMBER indicates that the measured result is below the MDC equal to the NUMBER.

Table A7. Inorganics with a Mixture of Measurements (mg/g) above and below their Minimum Detectable Concentrations

\begin{tabular}{|c|c|c|c|c|c|c|c|c|c|}
\hline Analyte & \multicolumn{3}{|c|}{ Composite Sample 1} & \multicolumn{3}{|c|}{ Composite Sample 2} & \multicolumn{3}{|c|}{ Composite Sample 3} \\
\hline $\mathrm{S}$ & $<2.70 \mathrm{E}-01$ & $<3.06 \mathrm{E}-01$ & 5.13E-01 & $<3.00 E-01$ & 2.90E-01 & $<3.00 \mathrm{E}-01$ & $3.62 \mathrm{E}-01$ & 4.09E-01 & $3.25 \mathrm{E}-01$ \\
\hline
\end{tabular}

$<$ NUMBER indicates that the measured result is below the MDC equal to the NUMBER.

Table A8. Anions with All Measurements (mg/g) above their Minimum Detectable Concentrations

\begin{tabular}{|c|c|c|c|c|c|c|c|c|c|}
\hline Analyte & \multicolumn{3}{|c|}{ Composite Sample 1} & \multicolumn{3}{|c|}{ Composite Sample 2} & \multicolumn{3}{|c|}{ Composite Sample 3} \\
\hline C2O4-2 & $1.96 \mathrm{E}+00$ & $1.87 \mathrm{E}+00$ & $1.90 \mathrm{E}+00$ & $2.24 \mathrm{E}+00$ & $2.42 \mathrm{E}+00$ & $2.30 \mathrm{E}+00$ & $2.65 \mathrm{E}+00$ & $2.66 \mathrm{E}+00$ & $2.86 \mathrm{E}+00$ \\
\hline $\mathrm{CHO} 2-1$ & 5.90E-01 & 5.60E-01 & $5.20 \mathrm{E}-01$ & $2.20 \mathrm{E}-01$ & $2.20 \mathrm{E}-01$ & $2.40 \mathrm{E}-01$ & 4.00E-01 & 4.00E-01 & $3.80 \mathrm{E}-01$ \\
\hline NO3-1 & $2.30 \mathrm{E}-01$ & $3.20 \mathrm{E}-01$ & $7.50 \mathrm{E}-02$ & $7.20 \mathrm{E}-02$ & $4.50 \mathrm{E}-02$ & $4.90 \mathrm{E}-02$ & $8.80 \mathrm{E}-02$ & $8.90 \mathrm{E}-02$ & $9.50 \mathrm{E}-02$ \\
\hline SO4-2 & $2.70 \mathrm{E}-01$ & $2.40 \mathrm{E}-01$ & $2.20 \mathrm{E}-01$ & $1.40 \mathrm{E}-01$ & $1.30 \mathrm{E}-01$ & $1.50 \mathrm{E}-01$ & $3.10 \mathrm{E}-01$ & 3.10E-01 & $3.30 \mathrm{E}-01$ \\
\hline
\end{tabular}

Table A9. Anions with All Measurements (mg/g) below their Minimum Detectable Concentrations

\begin{tabular}{|c|c|c|c|c|c|c|c|c|c|}
\hline Analyte & \multicolumn{3}{|c|}{ Composite Sample 1} & & & & \multicolumn{3}{|c|}{ Composite Sample 3} \\
\hline $\mathrm{F}-1$ & $<4.60 \mathrm{E}-02$ & $<4.00 \mathrm{E}-02$ & $<3.70 \mathrm{E}-02$ & $<3.60 \mathrm{E}-02$ & $<4.50 \mathrm{E}-02$ & $<4.90 \mathrm{E}-02$ & $<4.40 \mathrm{E}-02$ & $<4.40 \mathrm{E}-02$ & $<4.80 \mathrm{E}-02$ \\
\hline PO4-3 & $<4.60 \mathrm{E}-02$ & $<4.00 \mathrm{E}-02$ & $<3.70 \mathrm{E}-02$ & $<3.60 \mathrm{E}-02$ & $<4.50 \mathrm{E}-02$ & $<4.90 \mathrm{E}-02$ & $<4.40 \mathrm{E}-02$ & $<4.40 \mathrm{E}-02$ & $<4.80 \mathrm{E}-02$ \\
\hline
\end{tabular}

$<$ NUMBER indicates that the measured result is below the MDC equal to the NUMBER.

Table A10. Anions with a Mixture of Measurements (mg/g) above and below their Minimum Detectable Concentrations

\begin{tabular}{|c|c|c|c|c|c|c|c|c|c|}
\hline Analyte & \multicolumn{3}{|c|}{ Composite Sample 1} & \multicolumn{3}{|c|}{ Composite Sample 2} & \multicolumn{3}{|c|}{ Composite Sample 3} \\
\hline $\mathrm{Cl}-1$ & $4.60 \mathrm{E}-02$ & 4.00E-02 & $3.70 \mathrm{E}-02$ & $<3.60 \mathrm{E}-02$ & $4.50 \mathrm{E}-02$ & $4.90 \mathrm{E}-02$ & $<4.40 \mathrm{E}-02$ & $<4.40 \mathrm{E}-02$ & $<4.80 \mathrm{E}-02$ \\
\hline NO2-1 & $4.60 \mathrm{E}-02$ & 7.90E-02 & $<3.70 \mathrm{E}-02$ & $<3.60 \mathrm{E}-02$ & $<4.50 \mathrm{E}-02$ & $<4.90 \mathrm{E}-02$ & $<4.40 \mathrm{E}-02$ & $<4.40 \mathrm{E}-02$ & $<4.80 \mathrm{E}-02$ \\
\hline
\end{tabular}

$<$ NUMBER indicates that the measured result is below the MDC equal to the NUMBER. 


\section{Appendix B}

\section{Statistical Summary}

Table B1. Statistical Summary for the Sample Bulk Density $(\mathrm{g} / \mathrm{mL})$

\begin{tabular}{|l|c|c|c|c|c|l|}
\hline \multicolumn{9}{|c|}{ Table B1. Statistical Summary for the Sample Bulk Density (g/mL) } \\
\hline Constituent & $\mathbf{N}$ & Mean (g/mL) & Std Dev (g/mL) & \% Std Dev & UCL95 (g/mL) & Goodness-of-Fit/Confidence Limit Remarks \\
\hline Density & 9 & $1.35 \mathrm{E}+00$ & $4.82 \mathrm{E}-02$ & $3.56 \%$ & $1.38 \mathrm{E}+00$ & Normal W-S=0.859; Use Student's t UCL95 \\
\hline
\end{tabular}

" Goodness-of-Fit Note: Wilk-Shapiro (W-S) critical value at $\alpha=5 \%$ is 0.829 . Reject the hypothesized (normal or lognormal) distribution if W-S Statistic $<$ W-S critical value. 


\section{Appendix B}

Statistical Summary

Table B2. Statistical Summary for the Radionuclides ( $\mu \mathrm{Ci} / \mathrm{g}$ ) - All Measurements above their Minimum Detectable Concentrations

\begin{tabular}{|c|c|c|c|c|c|c|}
\hline Constituent & $\mathbf{N}$ & Mean ( $\mu \mathrm{Ci} / \mathrm{g})$ & Std Dev ( $\mu \mathrm{Ci} / \mathrm{g})$ & \% Std Dev & UCL95 ( $\mu \mathrm{Ci} / \mathrm{g})$ & Goodness-of-Fit/Confidence Limit Remarks ${ }^{\wedge}$ \\
\hline Am-241 & 9 & $7.00 \mathrm{E}+01$ & $4.68 \mathrm{E}+00$ & $6.69 \%$ & $7.29 \mathrm{E}+01$ & Normal W-S=0.899 ^; Use Student's t UCL95 \\
\hline Am-242m & 8 & $1.64 \mathrm{E}-01$ & $2.40 \mathrm{E}-02$ & $14.6 \%$ & $1.80 \mathrm{E}-01$ & Normal W-S=0.893 ; Use Student's t UCL95 \\
\hline Am-243 & 8 & $5.31 \mathrm{E}-01$ & $3.83 \mathrm{E}-02$ & $7.21 \%$ & $5.57 \mathrm{E}-01$ & Normal W-S=0.843 ; Use Student's t UCL95 \\
\hline Ba-137m & 9 & $3.92 \mathrm{E}+02$ & $4.71 \mathrm{E}+01$ & $12.00 \%$ & $4.21 \mathrm{E}+02$ & Normal W-S=0.880 A ; Use Student's t UCL95 \\
\hline $\mathrm{Cm}-242$ & 8 & $1.36 \mathrm{E}-01$ & 1.97E-02 & $14.5 \%$ & $1.49 \mathrm{E}-01$ & Normal W-S=0.893 $\mathbf{A}$; Use Student's t UCL95 \\
\hline $\mathrm{Cm}-244$ & 8 & $3.04 \mathrm{E}+00$ & 3.04E-01 & $10.0 \%$ & $3.24 \mathrm{E}+00$ & Normal W-S=0.933 ; Use Student's t UCL95 \\
\hline Co-60 & 9 & $6.81 \mathrm{E}+00$ & $4.41 \mathrm{E}-01$ & $6.48 \%$ & $7.08 \mathrm{E}+00$ & Normal W-S=0.911a; Use Student's t UCL95 \\
\hline Cs-135 & 9 & $2.12 \mathrm{E}-03$ & $3.21 \mathrm{E}-04$ & $15.2 \%$ & $2.31 \mathrm{E}-03$ & Normal W-S=0.951 A; Use Student's t UCL95 \\
\hline Cs-137 & 9 & $4.15 \mathrm{E}+02$ & $4.98 \mathrm{E}+01$ & $12.0 \%$ & $4.45 \mathrm{E}+02$ & Normal W-S=0.881 A; Use Student's t UCL95 \\
\hline Eu-154 & 9 & $2.99 \mathrm{E}+01$ & $1.61 \mathrm{E}+00$ & $5.38 \%$ & $3.09 \mathrm{E}+01$ & Normal W-S=0.964a; Use Student's t UCL95 \\
\hline Eu-155 & 9 & $5.07 \mathrm{E}+00$ & $1.26 \mathrm{E}+00$ & $24.8 \%$ & $5.86 \mathrm{E}+00$ & Normal W-S=0.878 ; Use Student's t UCL95 \\
\hline $\mathrm{Ni}-59$ & 9 & $5.52 \mathrm{E}+00$ & $1.22 \mathrm{E}+00$ & $22.0 \%$ & $6.27 \mathrm{E}+00$ & Normal W-S=0.968ณ; Use Student's t UCL95 \\
\hline $\mathrm{Ni}-63$ & 9 & $2.97 \mathrm{E}+02$ & $7.99 \mathrm{E}+01$ & $26.9 \%$ & $3.47 \mathrm{E}+02$ & Normal W-S=0.912 A; Use Student's t UCL95 \\
\hline Non-volatile beta & 9 & $2.97 \mathrm{E}+04$ & $1.57 \mathrm{E}+03$ & $5.29 \%$ & $3.07 \mathrm{E}+04$ & Normal W-S=0.962 A; Use Student's t UCL95 \\
\hline $\mathrm{Np}-237$ & 9 & $2.31 \mathrm{E}-02$ & 7.02E-03 & $30.4 \%$ & $2.74 \mathrm{E}-02$ & Normal W-S=0.847a; Use Student's t UCL95 \\
\hline Pd-107 & 9 & $3.76 \mathrm{E}-03$ & 1.99E-03 & $53.0 \%$ & $5.16 \mathrm{E}-03$ & $\begin{array}{l}\text { Not Normal W-S=0.753; Not Gamma A-D=0.836; } \\
\text { Data follow Approximate Gamma } \\
\text { Use Approximate Gamma UCL95. }\end{array}$ \\
\hline
\end{tabular}

"Goodness-of-Fit Note: $\wedge$ indicates that the goodness-of-fit test was passed: the data are consistent with the tested distribution.

The Wilk-Shapiro (W-S) critical value at $\alpha=5 \%$ is 0.829 when $n=9$ and 0.818 when $n=8$. Reject the hypothesized (normal or lognormal) distribution if W-S Statistic < W-S critical value.

The Anderson-Darling (A-D) gamma goodness-of-fit Critical Value at $\alpha=5 \%$ is 0.72 . Reject the hypothesized gamma distribution if $A-D$ statistic $>A-D$ critical value.

Table B2 continued on next page. 


\section{Appendix B}

\section{Statistical Summary}

Table B2 Continued. Statistical Summary for the Radionuclides ( $\mu \mathrm{Ci} / \mathrm{g}$ ) - All Measurements above their Minimum Detectable Concentrations

\begin{tabular}{|c|c|c|c|c|c|c|}
\hline Constituent & $\mathbf{N}$ & Mean ( $\mu \mathrm{Ci} / \mathrm{g})$ & Std Dev ( $\mu \mathrm{Ci} / \mathrm{g})$ & \% Std Dev & UCL95 ( $\mu \mathrm{Ci} / \mathrm{g})$ & Goodness-of-Fit/Confidence Limit Remarks \\
\hline Pu-238 & 9 & $2.59 \mathrm{E}+00$ & $2.72 \mathrm{E}-01$ & $10.5 \%$ & $2.76 \mathrm{E}+00$ & Normal W-S=0.960 A ; Use Student's t UCL95 \\
\hline Pu-239 & 9 & $8.22 \mathrm{E}+00$ & $1.13 \mathrm{E}+00$ & $11.3 \%$ & $8.88 \mathrm{E}+00$ & $\begin{array}{l}\text { Not Normal W-S=0.825; Not Gamma A-D=0.822; } \\
\text { Data follow Approx. Gamma. } \\
\text { Use Approx. Gamma UCL95 }\end{array}$ \\
\hline Pu-239/240 & 9 & $1.02 \mathrm{E}+01$ & $1.17 \mathrm{E}+00$ & $11.5 \%$ & $1.09 \mathrm{E}+01$ & Normal W-S=0.829 ; Use Student's t UCL95 \\
\hline $\mathrm{Pu}-240$ & 9 & $1.92 \mathrm{E}+00$ & $2.17 \mathrm{E}-01$ & $11.3 \%$ & $2.06 \mathrm{E}+00$ & Normal W-S=0.854 ; Use Student's t UCL95 \\
\hline $\mathrm{Pu}-242$ & 9 & 3.77E-04 & $5.28 \mathrm{E}-05$ & $14.0 \%$ & 4.10E-04 & Normal W-S=0.880 ; Use Student's t UCL95 \\
\hline Se-79 & 9 & $1.02 \mathrm{E}-02$ & $4.98 \mathrm{E}-03$ & $48.7 \%$ & $1.33 \mathrm{E}-02$ & Normal W-S=0.961 ; Use Student's t UCL95 \\
\hline Sm-151 & 9 & $7.79 \mathrm{E}+02$ & $5.51 \mathrm{E}+01$ & $7.08 \%$ & $8.13 \mathrm{E}+02$ & Normal W-S=0.915 A ; Use Student's t UCL95 \\
\hline Sr-90 & 9 & $1.20 \mathrm{E}+04$ & $8.75 E+02$ & $7.27 \%$ & $1.25 \mathrm{E}+04$ & $\begin{array}{l}\text { Not Normal W-S=0.812; Not Gamma A-D=0.779; } \\
\text { Data follow Approx. Gamma. } \\
\text { The result } 1.03 \mathrm{E}+04 \text { is a low-tail outlier } \\
\text { Use Approx. Gamma UCL95 }\end{array}$ \\
\hline $\begin{array}{l}\text { Sr-90 } \\
(\text { Omit } 1.03 E+4)\end{array}$ & 9 & $1.23 \mathrm{E}+04$ & $3.54 \mathrm{E}+02$ & $2.88 \%$ & $1.25 \mathrm{E}+04$ & $\begin{array}{l}\text { Normal W-S=0.974 } \text {; } \\
\text { The smallest (outlier) result } 1.03 \mathrm{E}+04 \text { is omitted. } \\
\text { Use Student's t UCL95* }\end{array}$ \\
\hline Tc-99 & 9 & $1.00 \mathrm{E}-02$ & $1.48 \mathrm{E}-03$ & $14.8 \%$ & $1.09 \mathrm{E}-02$ & Normal W-S=0.987 ^; Use Student's t UCL95 \\
\hline Th-230 & 9 & $1.55 \mathrm{E}-03$ & $1.12 \mathrm{E}-03$ & $72.3 \%$ & $2.25 \mathrm{E}-03$ & Normal W-S=0.903 ; Use Student's t UCL95 \\
\hline
\end{tabular}

"Goodness-of-Fit Note: $\boldsymbol{\wedge}$ indicates that the goodness-of-fit test was passed: the data are consistent with the tested distribution.

The Wilk-Shapiro (W-S) critical value at $\alpha=5 \%$ is 0.829 when $n=9$ and 0.818 when $n=8$. Reject the hypothesized (normal or lognormal) distribution if W-S Statistic < W-S critical value.

The Anderson-Darling (A-D) gamma goodness-of-fit critical value at $\alpha=5 \%$ is 0.72 . Reject the hypothesized gamma distribution if $A-D$ statistic $>A-D$ critical value.

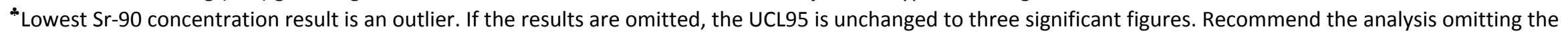
low-tail outlier.

Table B2 continued on next page. 


\section{Appendix B}

\section{Statistical Summary}

Table B2 Continued. Statistical Summary for the Radionuclides ( $\mu \mathrm{Ci} / \mathrm{g}$ ) - All Measurements above their Minimum Detectable Concentrations

\begin{tabular}{|c|c|c|c|c|c|c|}
\hline U-235 & 9 & 1.97E-04 & $2.36 \mathrm{E}-05$ & $12.0 \%$ & $2.12 \mathrm{E}-04$ & Normal W-S=0.974 ; Use Student's t UCL95 \\
\hline $\mathrm{U}-236$ & 9 & $2.42 \mathrm{E}-04$ & 2.77E-05 & $11.4 \%$ & $2.59 \mathrm{E}-04$ & Normal W-S=0.972 $\mathrm{A}$; Use Student's t UCL95 \\
\hline U-238 & 9 & $4.56 \mathrm{E}-03$ & $5.62 \mathrm{E}-04$ & $12.3 \%$ & $4.91 \mathrm{E}-03$ & Normal W-S=0.958 ; Use Student's t UCL95 \\
\hline Y-90 & 9 & $1.20 \mathrm{E}+04$ & $8.75 \mathrm{E}+02$ & $6.09 \%$ & $1.25 \mathrm{E}+04$ & $\begin{array}{l}\text { Not Normal W-S=0.812; Not Gamma A-D=0.779; } \\
\text { Data follow Approx. Gamma. } \\
\text { The result } 1.03 E+04 \text { is a low-tail outlier } \\
\text { Use Approx. Gamma UCL95 }\end{array}$ \\
\hline $\begin{array}{l}\text { Y-90 } \\
\text { (Omit 1.03E+4) }\end{array}$ & 9 & $1.23 \mathrm{E}+04$ & $3.54 \mathrm{E}+02$ & $2.88 \%$ & $1.25 \mathrm{E}+04$ & $\begin{array}{l}\text { Normal W-S=0.974 } \mathrm{A} \text {; } \\
\text { The smallest (outlier) result } 1.03 \mathrm{E}+04 \text { is omitted. } \\
\text { Use Student's t UCL95 }\end{array}$ \\
\hline Zr-93 & 9 & $2.99 \mathrm{E}+00$ & $2.55 \mathrm{E}-01$ & $8.54 \%$ & $3.14 \mathrm{E}+00$ & Normal W-S=0.866 ; Use Student's t UCL95 \\
\hline
\end{tabular}

`Goodness-of-Fit Note: $\wedge$ indicates that the goodness-of-fit test was passed: the data are consistent with the tested distribution.

The Wilk-Shapiro (W-S) critical value at $\alpha=5 \%$ is 0.829 when $n=9$ and 0.818 when $n=8$. Reject the hypothesized (normal or lognormal) distribution if W-S Statistic $<$ W-S critical value.

The Anderson-Darling (A-D) gamma goodness-of-fit critical value at $\alpha=5 \%$ is 0.72 . Reject the hypothesized gamma distribution if A-D statistic $>$ A-D critical value. *Lowest Y-90 concentration result is an outlier. If the results is omitted, the UCL95 is unchanged to three significant figures. Recommend the analysis omitting the low-tail outlier. 


\section{Appendix B}

\section{Statistical Summary}

Table B3. Statistical Summary for the Radionuclides ( $\mu \mathrm{Ci} / \mathrm{g}$ ) - All Measurements below their Minimum Detectable Concentrations

\begin{tabular}{|c|c|c|c|}
\hline Constituent & $\mathbf{N}$ & Smallest Minimum Detectable Concentration $(\mu \mathrm{Ci} / \mathrm{g})$ & Largest Minimum Detectable Concentration $(\mu \mathrm{Ci} / \mathrm{g})$ \\
\hline Ac-227 & 3 & $9.50 \mathrm{E}-05$ & $5.23 \mathrm{E}-04$ \\
\hline Al-26 & 3 & 1.29E-02 & $1.94 \mathrm{E}-02$ \\
\hline Bk-247 & 8 & $1.13 \mathrm{E}-03$ & $5.99 \mathrm{E}-03$ \\
\hline C-14 & 9 & 7.39E-04 & $3.40 \mathrm{E}-03$ \\
\hline Cf-249 & 8 & 7.39E-03 & $1.88 \mathrm{E}-02$ \\
\hline Cf- 250 & 8 & $1.52 \mathrm{E}-04$ & $1.02 \mathrm{E}-03$ \\
\hline Cf-251 & 8 & $1.65 \mathrm{E}-02$ & $5.05 \mathrm{E}-02$ \\
\hline Cf-252 & 8 & $1.05 \mathrm{E}-01$ & $1.57 \mathrm{E}-01$ \\
\hline $\mathrm{Cl}-36$ & 3 & $2.87 \mathrm{E}-03$ & $8.42 \mathrm{E}-03$ \\
\hline $\mathrm{Cm}-243$ & 9 & $5.77 \mathrm{E}-02$ & $1.40 \mathrm{E}+00$ \\
\hline $\mathrm{Cm}-245$ & 8 & $5.63 \mathrm{E}-04$ & $1.50 \mathrm{E}-03$ \\
\hline $\mathrm{Cm}-246$ & 8 & $1.04 \mathrm{E}-03$ & $3.22 \mathrm{E}-03$ \\
\hline $\mathrm{Cm}-247$ & 8 & $1.01 \mathrm{E}-07$ & 5.41E-07 \\
\hline $\mathrm{Cm}-248$ & 8 & $1.32 \mathrm{E}-05$ & $5.72 \mathrm{E}-05$ \\
\hline Eu-152 & 3 & $1.47 \mathrm{E}-01$ & $2.11 \mathrm{E}-01$ \\
\hline Gross Alpha & 9 & $2.09 \mathrm{E}+02$ & $1.07 \mathrm{E}+03$ \\
\hline $\mathrm{H}-3$ & 9 & 8.37E-03 & $1.83 \mathrm{E}-02$ \\
\hline $\mathrm{K}-40$ & 3 & $8.24 \mathrm{E}-04$ & $5.14 \mathrm{E}-03$ \\
\hline $\mathrm{Nb}-94$ & 3 & $1.14 \mathrm{E}-03$ & $2.87 \mathrm{E}-03$ \\
\hline Pa-231 & 8 & $1.41 \mathrm{E}-04$ & $1.02 \mathrm{E}-03$ \\
\hline Pm-147 & 9 & $4.59 \mathrm{E}+02$ & $6.40 \mathrm{E}+02$ \\
\hline Pt-193 & 5 & $4.24 \mathrm{E}-04$ & $1.56 \mathrm{E}-03$ \\
\hline Pu-241 & 9 & $8.51 \mathrm{E}+00$ & $1.37 \mathrm{E}+01$ \\
\hline $\mathrm{Pu}-244$ & 9 & $7.43 \mathrm{E}-07$ & $1.18 \mathrm{E}-06$ \\
\hline Ra-226 & 3 & $6.81 \mathrm{E}-04$ & $9.78 \mathrm{E}-03$ \\
\hline Sb-126 & 3 & $1.04 \mathrm{E}-01$ & $1.50 \mathrm{E}-01$ \\
\hline $\mathrm{Sb}-126 \mathrm{~m}$ & 3 & $1.04 \mathrm{E}-01$ & $1.50 \mathrm{E}-01$ \\
\hline Sn-126 & 3 & 8.06E-01 & $1.18 \mathrm{E}+00$ \\
\hline U-232 & 9 & 4.62E-06 & $3.47 \mathrm{E}-05$ \\
\hline U-233 & 9 & $2.34 \mathrm{E}-04$ & $7.58 \mathrm{E}-03$ \\
\hline
\end{tabular}




\section{Appendix B}

\section{Statistical Summary}

Table B4. Statistical Summary for the Radionuclides ( $\mu \mathrm{Ci} / \mathrm{g}$ ) - Mixture of Measurements above and below their Minimum Detectable Concentrations

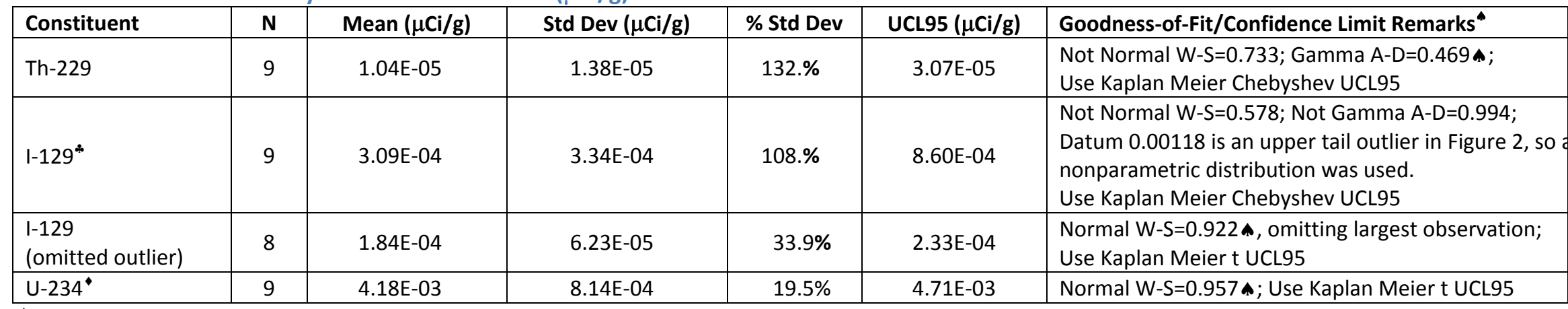

"Goodness-of-Fit Note: $\uparrow$ indicates that the goodness-of-fit test was passed: the data are consistent with the tested distribution.

The Wilk-Shapiro (W-S) Critical Value at $\alpha=5 \%$ is 0.818 for $n=9$ and 0.803 for $n=8$. Reject the hypothesized distribution (normal or lognormal) if W-S Statistic < W-S critical value.

The Anderson-Darling (A-D) goodness-of-fit critical value at $\alpha=5 \%$ is 0.736 for Th-229 and 0.727 for I-129. Reject the hypothesized gamma distribution if A-D statistic $>$ A-D critical value.

- The nine I-229 concentration results contain an outlier (1.18E-3). In the following row, the normal distribution fits when the outlier is omitted ( $\mathrm{n}=8$ ) from the I129 data set. Kaplan-Meier estimators were used. Refer to the supplemental plot on the following page.

- Using the normal assumption, the maximum likelihood estimators for the true mean and true standard deviation for U-234 failed to converge properly. The sample mean and standard deviation were computed by substituting $1 \frac{1}{2}$ of the MDC for measurement 3 on composite sample 2 . 


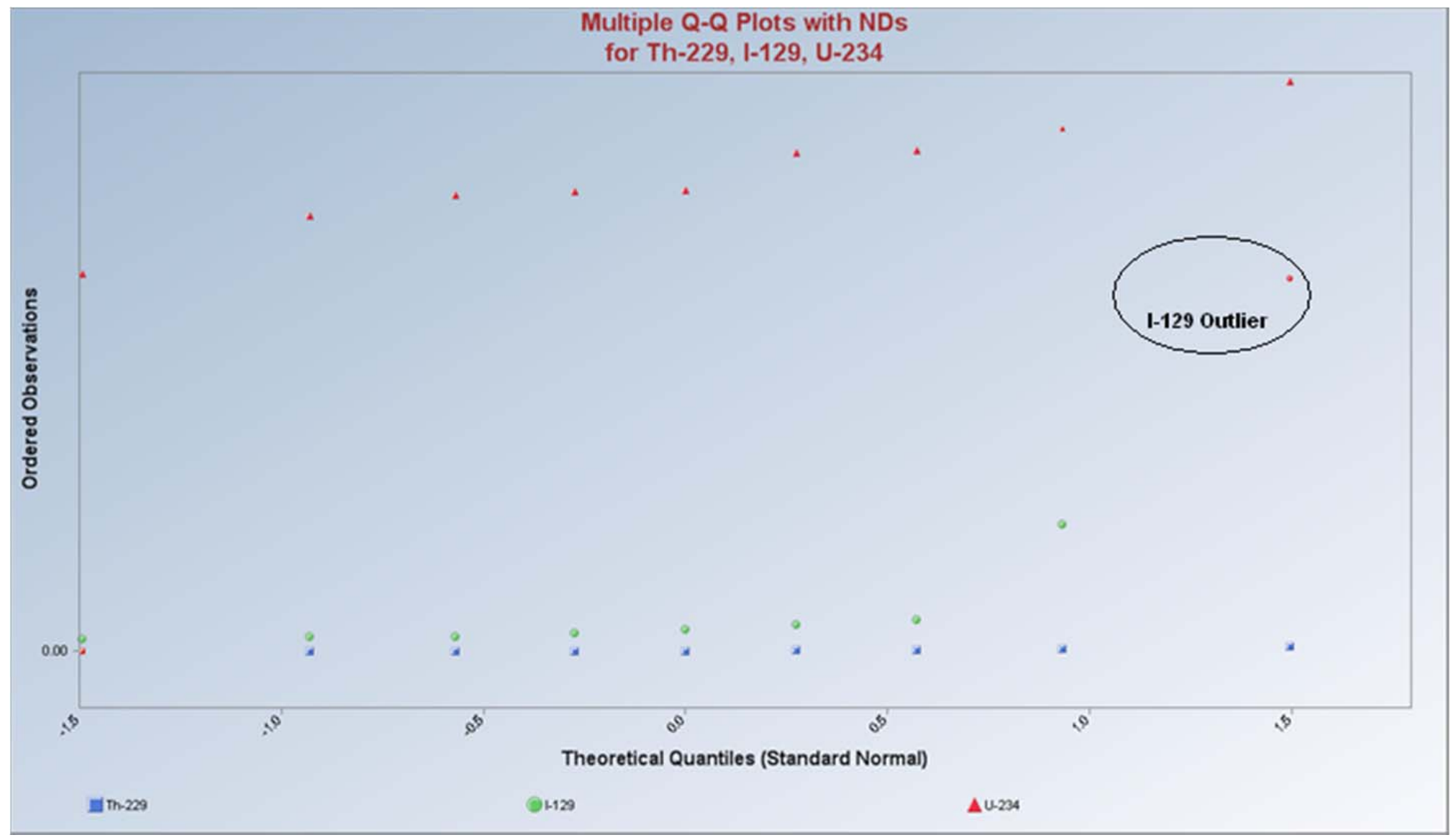

Supplemental Plot to Table B4: Plot of Th-229, I-129, and U-234 Concentration Results vs. their Theoretical Normal Quantiles Plot shows the potential outlier in the I-129 data set (results denoted by circles). 


\section{Appendix B}

\section{Statistical Summary}

Table B5. Statistical Summary for the Inorganics (mg/g) - All Measurements above their Minimum Detectable Concentrations

\begin{tabular}{|c|c|c|c|c|c|c|}
\hline Constituent & $\mathbf{N}$ & Mean (mg/g) & Std Dev (mg/g) & \% Std Dev & UCL95 (mg/g) & Goodness-of-Fit/Confidence Limit Remarks \\
\hline $\mathrm{Ag}$ & 9 & $2.46 \mathrm{E}-01$ & 3.57E-02 & $14.5 \%$ & $2.68 \mathrm{E}-01$ & Normal W-S=0.875^; Use Student's t UCL95 \\
\hline Al & 9 & $4.84 \mathrm{E}+00$ & $1.46 \mathrm{E}+00$ & $30.1 \%$ & $6.96 \mathrm{E}+00$ & $\begin{array}{l}\text { Not Normal W-S=0.509; Not Gamma A-D=1.944 } \\
\text { Not Lognormal W-S=0.562; } \\
\text { Use Student's t UCL95 because \% Std Dev }<50 \% \text {. }\end{array}$ \\
\hline $\mathrm{B}$ & 9 & $1.30 \mathrm{E}+00$ & $8.12 \mathrm{E}-02$ & $6.23 \%$ & $1.35 \mathrm{E}+00$ & Normal W-S=0.915 ; Use Student's t UCL95 \\
\hline $\mathrm{Ba}$ & 9 & $1.94 \mathrm{E}+00$ & $1.42 \mathrm{E}-01$ & $7.32 \%$ & $2.03 \mathrm{E}+00$ & Normal W-S=0.898 ; Use Student's t UCL95 \\
\hline $\mathrm{Be}$ & 9 & $1.21 \mathrm{E}-02$ & 7.31E-04 & $6.04 \%$ & $1.26 \mathrm{E}-02$ & Normal W-S=0.909 ^; Use Student's t UCL95 \\
\hline $\mathrm{Ca}$ & 9 & $1.54 \mathrm{E}+00$ & $1.55 \mathrm{E}-01$ & $10.1 \%$ & $1.63 \mathrm{E}+00$ & Normal W-S=0.872 A ; Use Student's t UCL95 \\
\hline $\mathrm{Cd}$ & 9 & $8.93 \mathrm{E}-02$ & $5.37 \mathrm{E}-03$ & $6.01 \%$ & $9.27 \mathrm{E}-02$ & Normal W-S=0.969 ^ ; Use Student's t UCL95 \\
\hline $\mathrm{Ce}$ & 9 & $2.54 \mathrm{E}+00$ & $4.66 \mathrm{E}-01$ & $18.3 \%$ & $2.83 \mathrm{E}+00$ & Normal W-S=0.885 ; Use Student's t UCL95 \\
\hline Co & 9 & $2.14 \mathrm{E}-01$ & $2.35 \mathrm{E}-02$ & $11.0 \%$ & $2.28 \mathrm{E}-01$ & Normal W-S=0.836^; Use Student's t UCL95 \\
\hline $\mathrm{Cr}$ & 9 & $1.05 \mathrm{E}+00$ & $1.31 \mathrm{E}-01$ & $12.5 \%$ & $1.24 \mathrm{E}+00$ & $\begin{array}{l}\text { Not Normal W-S=0.612; Not Gamma A-D=1.419; } \\
\text { Not Lognormal W-S=0.648; } \\
\text { Use Student's t UCL95 because \% Std Dev }<50 \% \text {. }\end{array}$ \\
\hline $\mathrm{Cu}$ & 9 & 7.20E-01 & $9.64 \mathrm{E}-02$ & $13.4 \%$ & 8.61E-01 & $\begin{array}{l}\text { Not Normal W-S=0.758; Not Gamma A-D=0.785, } \\
\text { but follow Approximate Gamma ; } \\
\text { Use Approximate Gamma UCL95. }\end{array}$ \\
\hline $\mathrm{Fe}$ & 9 & $4.87 \mathrm{E}+02$ & $3.09 E+01$ & $6.34 \%$ & $5.06 \mathrm{E}+02$ & Normal W-S=0.899 $;$; Use Student's t UCL95 \\
\hline Gd & 9 & $1.96 \mathrm{E}-01$ & $4.36 \mathrm{E}-03$ & $2.23 \%$ & $2.02 \mathrm{E}-01$ & $\begin{array}{l}\text { Not Normal W-S=0.763; Not Gamma A-D=1.093; } \\
\text { Not Lognormal W-S=0.766; Use Student's t UCL95 } \\
\text { because \% Std Dev }<50 \% \text {. }\end{array}$ \\
\hline $\mathrm{Hg}$ & 9 & $2.26 \mathrm{E}+00$ & $3.05 \mathrm{E}-01$ & $13.5 \%$ & $2.45 \mathrm{E}+00$ & Normal W-S=0.875 ; Use Student's t UCL95 \\
\hline $\mathrm{K}$ & 9 & 3.19E-01 & $6.39 \mathrm{E}-02$ & $20.0 \%$ & $3.58 \mathrm{E}-01$ & Normal W-S=0.923 ; Use Student's t UCL95 \\
\hline
\end{tabular}

'Goodness-of-Fit Note: $\wedge$ indicates that the goodness-of-fit test was passed: the data are consistent with the tested distribution.

The Wilk-Shapiro (W-S) critical value at $\alpha=5 \%$ is 0.829 for $n=9$. Reject the (normal or lognormal) hypothesized distribution if W-S Statistic < W-S critical value. The Anderson-Darling (A-D) gamma goodness-of-fit critical value at $\alpha=5 \%$ is 0.72 . Reject the hypothesized gamma distribution if A-D statistic $>$ A-D critical value.

Table B5 continued on next page.

Appendix B

Statistical Summary 
SRNL-STI-2011-00613, Revision 0

Statistical Analysis of Tank 5 Floor Sample Results (U)

March 14, 2012

Page 24

Table B5 Continued. Statistical Summary for the Inorganics (mg/g) - All Measurements above their Minimum Detectable Concentrations

\begin{tabular}{|c|c|c|c|c|c|c|}
\hline Constituent & $\mathbf{N}$ & Mean (mg/g) & Std Dev (mg/g) & \% Std Dev & UCL95 (mg/g) & Goodness-of-Fit/Confidence Limit Remarks \\
\hline La & 9 & $1.42 \mathrm{E}+00$ & 1.67E-01 & $11.7 \%$ & $1.52 \mathrm{E}+00$ & Normal W-S=0.911 ; Use Student's t UCL95 \\
\hline Li & 9 & $5.09 \mathrm{E}-01$ & 7.51E-02 & $14.7 \%$ & $5.56 \mathrm{E}-01$ & Normal W-S=0.939 ; Use Student's t UCL95 \\
\hline $\mathrm{Mg}$ & 9 & 4.89E-01 & 2.37E-02 & $4.84 \%$ & $5.04 \mathrm{E}-01$ & Normal W-S=0.960 A ; Use Student's t UCL95 \\
\hline $\mathrm{Mn}$ & 9 & $3.37 \mathrm{E}+01$ & $2.68 \mathrm{E}+00$ & $7.95 \%$ & $3.53 \mathrm{E}+01$ & Normal W-S=0.929A; Use Student's t UCL95 \\
\hline Mo & 9 & $4.66 \mathrm{E}-02$ & $2.78 \mathrm{E}-03$ & $5.96 \%$ & $4.83 \mathrm{E}-02$ & Normal W-S=0.869 A ; Use Student's t UCL95 \\
\hline $\mathrm{Na}$ & 9 & $3.78 \mathrm{E}+00$ & $2.44 \mathrm{E}-01$ & $6.47 \%$ & $3.93 E+00$ & Normal W-S=0.832 A; Use Student's t UCL95 \\
\hline $\mathrm{Ni}$ & 9 & $5.52 \mathrm{E}+01$ & $7.08 \mathrm{E}+00$ & $12.8 \%$ & $5.96 \mathrm{E}+01$ & Normal W-S=0.903 $\mathrm{A}$; Use Student's t UCL95 \\
\hline $\mathrm{P}$ & 9 & $2.73 \mathrm{E}-01$ & 4.50E-02 & $16.5 \%$ & $3.00 \mathrm{E}-01$ & Normal W-S=0.917A; Use Student's t UCL95 \\
\hline $\mathrm{Pb}$ & 9 & $3.68 \mathrm{E}+00$ & $1.58 \mathrm{E}-01$ & $4.29 \%$ & $3.78 \mathrm{E}+00$ & Normal W-S=0.950 A ; Use Student's t UCL95 \\
\hline $\mathrm{Si}$ & 9 & $1.10 \mathrm{E}+00$ & $3.35 \mathrm{E}-01$ & $30.4 \%$ & $1.31 \mathrm{E}+00$ & Normal W-S=0.965 ; Use Student's t UCL95 \\
\hline Sn & 9 & 4.13E-02 & $5.29 \mathrm{E}-03$ & $12.8 \%$ & $4.46 \mathrm{E}-02$ & Normal W-S=0.968 ; Use Student's t UCL95 \\
\hline $\mathrm{Sr}$ & 9 & $3.78 \mathrm{E}-01$ & $3.03 \mathrm{E}-02$ & $8.03 \%$ & 3.97E-01 & Normal W-S=0.901 A; Use Student's t UCL95 \\
\hline $\mathrm{Ti}$ & 9 & $2.49 \mathrm{E}-01$ & $1.72 \mathrm{E}-02$ & $6.91 \%$ & $2.60 \mathrm{E}-01$ & Normal W-S=0.970 A ; Use Student's t UCL95 \\
\hline $\mathrm{U}$ & 9 & $8.93 \mathrm{E}+00$ & $1.03 \mathrm{E}+00$ & $11.6 \%$ & $9.57 \mathrm{E}+00$ & Normal W-S=0.967^; Use Student's t UCL95 \\
\hline $\mathrm{Zn}$ & 9 & $4.45 \mathrm{E}-01$ & $9.81 \mathrm{E}-02$ & $22.1 \%$ & 5.09E-01 & $\begin{array}{l}\text { Not Normal W-S=0.813; Gamma A-D=0.648 } \text {; } \\
\text { Use Approximate Gamma UCL95. }\end{array}$ \\
\hline $\mathrm{Zr}$ & 9 & $4.28 \mathrm{E}+00$ & 4.69E-01 & $11.0 \%$ & $4.57 \mathrm{E}+00$ & Normal W-S=0.949 ; Use Student's t UCL95 \\
\hline
\end{tabular}

'Goodness-of-Fit Note: $\wedge$ indicates that the goodness-of-fit test was passed: the data are consistent with the tested distribution.

The Wilk-Shapiro (W-S) critical value at $\alpha=5 \%$ is 0.829 . Reject the (normal or lognormal) hypothesized distribution if W-S Statistic $<$ W-S critical value.

The Anderson-Darling (A-D) gamma goodness-of-fit critical value at $\alpha=5 \%$ is 0.721 . Reject the hypothesized gamma distribution if A-D statistic $>$ A-D critical value. 
Appendix B

Statistical Summary

Table B6. Statistical Summary for the Inorganics (mg/g) - All Measurements below their Minimum Detectable Concentrations

\begin{tabular}{|l|c|c|c|}
\hline Constituent & $\mathbf{N}$ & Smallest Minimum Detectable Concentration (mg/g) & Largest Minimum Detectable Concentration (mg/g) \\
\hline As & 9 & $9.44 \mathrm{E}-03$ & $1.07 \mathrm{E}-02$ \\
\hline $\mathrm{Sb}$ & 9 & $7.67 \mathrm{E}-01$ & $8.68 \mathrm{E}-01$ \\
\hline $\mathrm{Se}$ & 9 & $2.00 \mathrm{E}-03$ & $2.10 \mathrm{E}-02$ \\
\hline $\mathrm{Th}$ & 9 & $3.90 \mathrm{E}-01$ & $4.40 \mathrm{E}-01$ \\
\hline $\mathrm{V}$ & 9 & $3.40 \mathrm{E}-02$ & $4.00 \mathrm{E}-02$ \\
\hline
\end{tabular}




\section{Appendix B}

\section{Statistical Summary}

Table B7. Statistical Summary for the Inorganics (mg/g) - Mixture of Measurements above and below the Minimum Detectable Concentrations

\begin{tabular}{|l|c|c|c|c|c|l|}
\hline Constituent $^{\star}$ & $\mathbf{N}$ & Mean (mg/g) & Std Dev (mg/g) & \% Std Dev & UCL95 (mg/g) & Goodness-of-Fit/Confidence Limit Remarks \\
\hline S & 9 & $2.76 \mathrm{E}-01$ & $1.37 \mathrm{E}-01$ & $49.6 \%$ & $3.90 \mathrm{E}-01$ & Normal W-S=0.947 $\mathbf{~ ; ~ U s e ~ K a p l a n ~ M e i e r ~ t ~ U C L 9 5 ~}$ \\
\hline
\end{tabular}

"Goodness-of-Fit Note: The Wilk-Shapiro (W-S) critical value at $\alpha=5 \%$ is 0.762 for $n=9$ of which 5 are below their MDCs. Reject the hypothesized normal distribution if W-S Statistic $<$ W-S critical value.

Table B8. Statistical Summary for the Anions (mg/g) - All Measurements above their Minimum Detectable Concentrations

\begin{tabular}{|c|c|c|c|c|c|c|}
\hline Constituent & $\mathbf{N}$ & Mean $(\mathrm{mg} / \mathrm{g})$ & Std Dev (mg/g) & \% Std Dev & UCL95 (mg/g) & Goodness-of-Fit/Confidence Limit Remarks \\
\hline C2O4-2 & 9 & $2.32 \mathrm{E}+00$ & $3.61 \mathrm{E}-01$ & $15.6 \%$ & $2.54 \mathrm{E}+00$ & Normal W-S=0.928 ; Use Student's t UCL95 \\
\hline $\mathrm{CHO} 2-1$ & 9 & $3.92 \mathrm{E}-01$ & $1.44 \mathrm{E}-01$ & $36.8 \%$ & $4.82 \mathrm{E}-01$ & Normal W-S=0.893 $\uparrow$; Use Student's t UCL95 \\
\hline NO3-1 & 9 & $1.18 \mathrm{E}-01$ & $9.33 \mathrm{E}-02$ & $79.0 \%$ & $2.11 \mathrm{E}-01$ & $\begin{array}{l}\text { Not Normal W-S=0.736; Not Gamma A-D }=0.776 \\
\text { Lognormal W-S=0.879 ; } \\
\text { Use Lognormal H UCL95 with \% Std Dev }<50 \% \text {. }\end{array}$ \\
\hline SO4-2 & 9 & $2.33 \mathrm{E}-01$ & $7.83 \mathrm{E}-02$ & $33.5 \%$ & $2.82 \mathrm{E}-01$ & Normal W-S=0.894 $\uparrow$; Use Student's t UCL95 \\
\hline
\end{tabular}

"Goodness-of-Fit Note: The Wilk-Shapiro (W-S) critical value at $\alpha=5 \%$ is 0.829 . Reject the hypothesized (normal or lognormal) distribution if W-S Statistic $<$ W-S critical value. The Anderson-Darling (A-D) gamma goodness-of-fit critical value at $\alpha=5 \%$ is 0.726 . Reject the hypothesized gamma distribution if A-D statistic $>A-D$ critical value.

Table B9. Statistical Summary for the Anions (mg/g) - All Measurements below their Minimum Detectable Concentrations
\begin{tabular}{|l|c|c|c|}
\hline Constituent & N & Smallest Minimum Detectable Concentration $\mathbf{( m g} / \mathbf{g})$ & Largest Minimum Detectable Concentration (mg/g) \\
\hline F-1 & 9 & $3.60 \mathrm{E}-02$ & $4.90 \mathrm{E}-02$ \\
\hline PO4-3 & 9 & $3.60 \mathrm{E}-02$ & $4.90 \mathrm{E}-02$ \\
\hline
\end{tabular}

Table B10. Statistical Summary for the Anions (mg/g) - Mixture of Measurements above and below their Minimum Detectable Concentrations

\begin{tabular}{|l|c|c|c|c|c|l|}
\hline Constituent & $\mathbf{N}$ & Mean (mg/g) & Std Dev (mg/g) & \% Std Dev & UCL95 (mg/g) & Goodness-of-Fit Remarks \\
\hline Cl-1 & 9 & $3.37 \mathrm{E}-02$ & $1.21 \mathrm{E}-02$ & $35.9 \%$ & $4.44 \mathrm{E}-02$ & Normal W-S=0.953 $\mathbf{A} ;$ Use Kaplan Meier t UCL95 \\
\hline NO2-1 & 9 & $4.97 \mathrm{E}-02$ & $1.04 \mathrm{E}-02$ & $20.9 \%$ & $5.188-02$ & $\begin{array}{l}\text { No Available Goodness-of-Fit Tests since only 2 } \\
\text { results are above MDCS; Nonparametric } \\
\text { estimators of Mean \& SD; Use Kaplan Meier t } \\
\text { UCL95 due to \% Std Dev < 50\%. }\end{array}$ \\
\hline
\end{tabular}




\section{Distribution:}

Department of Energy
P.R. Jackson
Office of Laboratory Oversight

Savannah River Remediation LLC
G.C. Arthur
Tank Farm and Closure Engineering
P.E. Carroll
Mechanical Closure and Isolation
D.J. Clark
Waste Retrieval
W.B. Dean
Organization Closure and Disposal Assessment

M.J. Mahoney

Manager, Closure and Waste Disposal Determination

B.A. Martin

Closure and Waste Disposal Determination

J.P. Pavletich

Closure and Waste Disposal Determination

K.H. Rosenberger

Manager, Organization Closure and Disposal Assessment

S.A. Thomas

Closure and Waste Disposal Authority

A.J. Tisler

Tank Farm and Closure Engineering

D.R. Watkins

Tetra Tech
A.W. Wiggins
Closure and Waste Disposal Determination

Savannah River National Laboratory

T. B. Edwards Applied Computational Engineering and Statistics

P.L. Lee

Manager, Applied Computational Engineering and Statistics

S.P. Harris

Applied Computational Engineering and Statistics

S.J. Hensel

Manager, Applied Computational Engineering and Sciences

S. L. Marra

Manager, E\&CPT Research Programs

L.N. Oji

Advanced Characterization and Processing

F.M. Pennebaker

Manager, Advanced Characterization and Processing

S.H. Reboul

Process Technology Programs

R.H. Young

Analytical Development 